\title{
Spatio-temporal dynamics of forage and land cover changes in Karamoja sub-region, Uganda
}

\author{
Anthony Egeru ${ }^{1,3^{*}}$, Oliver Wasonga ${ }^{2}$, Joseph Kyagulanyi ${ }^{4}$, GJ Mwanjalolo Majaliwa ${ }^{4}$, Laban MacOpiyo ${ }^{5}$ \\ and John Mburu ${ }^{5}$
}

\begin{abstract}
Spatio-temporal dynamics of pastoral grazing resources influences the pastoral production system. Obtaining timely and reliable information on the status of these resources will support planning and early response to climatic variability. This study in Karamoja pastoral sub-region of Uganda identified herbaceous and woody forage species in different grazing land cover types, quantified forage in different grazing land covers, analyzed long-term land use/cover change (from 1986 to 2013) and determined the relationship between Normalized Difference Vegetation Index (NDVI) and herbaceous biomass. Results showed that the sub-region has over 30 grass species that provide forage. During the wet season, woodlands, grasslands and thickets and shrublands recorded a wet weight of 1,342.5 $\pm 104.5 \mathrm{~kg} / \mathrm{ha}, 857.5 \pm 29.4 \mathrm{~kg} / \mathrm{ha}$ and $501 \pm 43.9 \mathrm{~kg} / \mathrm{ha}$, respectively. In the dry season, $542.5 \pm 57.6 \mathrm{~kg} / \mathrm{ha}, 273 \pm 6.4 \mathrm{~kg} / \mathrm{ha}$ and $140 \pm 9.2 \mathrm{~kg} / \mathrm{ha}$ were realized in the woodlands, grasslands and thickets and shrublands, respectively. However, in the transitionary season, 276, 512.5 and $529.2 \mathrm{~kg} / \mathrm{ha}$ were obtained in the woodlands, grasslands and thickets and shrublands accordingly. Similar trends were observed in dry matter biomass in the respective land cover type. Seasonality, land cover type and location accounted for the variations in the observed forage quantities. Analysis of land cover and land use change revealed a tenfold increase in croplands in the last 13 years. The expansion of crop cultivation is attributed to interventions by the Government of Uganda and development partners to promote food security in the sub-region. Heightened bushland encroachment was similarly observed in the last 13 years. The study also found a significant positive relationship between NDVI and herbaceous biomass, indicating that remote sensing offers reliable resource assessment and monitoring options for informing planning and interventions in semi-arid areas.
\end{abstract}

Keywords: Dry matter; Bush encroachment; Above-ground herbaceous biomass; Heterogeneity

\section{Background}

Livestock rearing has continued to play a significant role in the economy and welfare of Uganda. About $71 \%$ of households in Uganda owned livestock in 2008 (MAAIF and UBOS 2010). Previous estimates were of livestock and livestock products accounting for over $5 \%$ of the gross domestic product (GDP) and about 14\% of the agricultural GDP as well as a range of valuable services and products for domestic and export markets (FAO 2005). Newer estimates show that livestock contributes up to $3.2 \%$ to national GDP, larger than the GDP derived from either cash crops or fishing. Further, the share

\footnotetext{
* Correspondence: egeru81@gmail.com

'Department of Land Resource Management and Agricultural Technology,

University of Nairobi, P.O. Box 29053-00625, Nairobi, Kenya

${ }^{3}$ Department of Agricultural Engineering, Makerere University, P.O. Box 7062 , Kampala, Uganda

Full list of author information is available at the end of the article
}

contribution of livestock to Uganda's GDP is steadily rising (Behnke and Nakirya 2012). For the poorer livestock keepers of Uganda, livestock is hailed for its multiple benefits including facilitating saving, providing security, asset accumulation, financing planned and uncertain expenditures, providing a diversity of products and maintenance of social capital (Ashley and Nanyeenya 2002). The 'cattle corridor' of Uganda is the most important livestock herding region in the country. This semi-arid region runs diagonally across Uganda from southwestern (Ankole sub-region) to northeastern Uganda (Karamoja sub-region). Livestock herded in this region by pastoralists and agro-pastoralists accounts for over $90 \%$ of the national livestock herd. In Karamoja, livestock is interwoven in the socio-cultural fabric of the people. Livestock influences relationships and determines self-worth and existence in a community, and livestock are central 
in traditional ceremonies and rites of passage, in particular, marriage (Grade et al. 2009). Karamoja's livestock alone constitute about $10 \%$ of the national livestock herd, $20 \%$ of the national cattle herd, $16 \%$ of goats, $60 \%$ of all horses, 97\% of all camels and 91\% of all donkeys in Uganda (MAAIF and UBOS 2010).

Like most of the pastoral groups in eastern Africa such as the Turkana of Kenya, Toposa of Sudan and the Nyangatom, Rendille and Borana of Ethiopia, the Karamojong practice mobile livestock herding. Men, often energetic youth locally known as karachunas, and their livestock seasonally move between wet and dry season grazing areas (Grade et al. 2009). During such times, women, children and elders remain behind in the manyattas (semi-permanent homesteads). It is therefore evident that the Karamojong still exercise a self-provisioning form of livestock rearing - pastoralism (Weber and Horst 2011). This form of livestock rearing largely depends on the availability of natural resources on the range which are managed primarily by livestock and fire (Bassett and Crumney 2003). The use of these primary management tools has enabled pastoralists to manipulate grazing regimes and circumvent patchy vegetation. In so doing, they have been able to effect subsequent changes in land cover over time (Weber and Horst 2011) as well as survive the harsh realities of climatic variability.

A growing concern among scientists (e.g. Lambin et al. 2003; Oba 2012; Nelson 2012) focused on pastoral regions is how the current trends in land use and land cover are affecting the grazing resource base. These shifts in land use are largely externally driven and have set in motion a myriad of other challenges including restricted mobility of pastoral herds, reductions in grazing lands and increased conflicts, especially those between farming and pastoral communities (Campbell et al. 2003; Nelson 2012; Oba 2012). The fact that changes in land use and land cover affect forage availability has implications for the viability of the pastoral livestock production and therefore livelihoods of pastoral communities in the region. The consequence of diminishing grazing lands is exemplified by livestock losses and exit of pastoralists among the pastoral Rufa'a Al Hoi ethnic group of the Blue Nile State in Sudan (Ahmed 2009). Similar trends have been reported in Burkina Faso among the Fulani pastoral communities (Tenuche and Ifatimehin 2009; Madu 2012). In eastern Africa, land use and land cover change dynamics are evident in privatization of pastoral land and sedentarisation in pastoral communities (Lesorogol 2005). In Uganda, livestock keepers in Kaliro district have experienced shortage in forage (Tabuti and Lye 2009) due to conversion of communal grazing lands for agriculture. Such processes exacerbate the vulnerability of pastoral groups to the vagaries of nature, particularly the devastating impacts of climate variability that include livestock losses and reduced livestock productivity (Nyariki et al. 2009; Kirwa et al. 2012; Nelson 2012).

Unlike other rangeland ecosystems in the east African region, minimal assessment and monitoring of forage and grazing land use changes has been undertaken in the Karamoja sub-region of Uganda. This is particularly attributed to prolonged periods of conflict and civil unrest that have plagued the sub-region. With the return of relative peace, security and stability, there has been increased promotion of sedentarisation and crop cultivation ostensibly to promote food security (Wamani and Bagonza 2013; Avery 2014). As a result, the pastoralist system in Karamoja is undergoing radical changes that are negatively affecting the pastoral livestock production (Anderson and Robinson 2009).

The ongoing conversion of rangelands to croplands has not been adequately addressed. Limited efforts (e.g. Nakalembe 2013; Scott-Villiers 2013) have been channeled towards examining the extent to which the changes, particularly in the grazing landscapes, have occurred over time. Nonetheless, a few studies have attempted to provide insights into the land use and land cover changes in Karamoja sub-region. One such study conducted in Moroto district indicated that deforestation was the most significant biophysical change occurring in the district (Majaliwa et al. 2009). In addition, vegetation cover and pasture resources were reported to have undergone significant changes in the area. No study has attempted to provide a sub-regional analysis of land use and land cover changes and how they impact on extensive livestock production system in the Karamoja sub-region, and yet, pastoralism is still the main livelihood activity for the Karamojong community. Mobile pastoral production systems traverse administrative borders, and therefore, their assessment requires a landscape approach so as to provide decision-makers with a sub-regional status of grazing resources. It is against this background that the 10th European Development Fund (EDF) Karamoja Livelihoods Programme (KALIP) recommended that a full study be undertaken of pasture availability by season and location in the sub-region (Anderson and Robinson 2009).

Sustainability of grazing and forage resources in pastoral areas requires the assessment and routine monitoring of spatio-temporal distribution and changes of these resources, as well as the awareness of the drivers of the observed change dynamics (Feng et al. 2009). Pastoralists have developed their own rangeland assessment and monitoring systems based on indigenous knowledge (Oba 2012). However, where changes are rapid and unrecorded, earth observations from space provide objective information on human use of the landscape (Ruelland et al. 2010). Remote sensing further plays a pivotal role in guiding grazing management by providing information in support of analysis, modeling and forecasting for decision support 
(Angerer 2008; Kawamura and Akiyama 2010). However, the relevance of satellite imagery in providing information to address challenges relating to livestock grazing resources will be greater when satellite data is integrated with groundbased assessments. The ground-based assessments help to fill the gaps in the satellite data particularly with regard to the composition of vegetation resources (Xie et al. 2008; Gintzburger and Saïdi 2009). A dearth of comparable empirical knowledge exists regarding the current real spatial and quantitative extent of forage resources in Karamoja subregion. Therefore, this study (i) identified herbaceous and woody forage species in the grazing land covers, (ii) quantified the extent of the land use/land cover change in Karamoja and compared land cover change rates over time, (iii) quantified the potential available forage in the subregion by integrating clipped wet weight and dry matter and related this to the extent of each grazing land cover and (iv) determined the relationship between Normalized Difference Vegetation Index (NDVI) and herbaceous biomass.

\section{Study area}

Karamoja is located in northeastern Uganda (Figure 1) and is bordered to the east by the Rift valley escarpment that drops down into the Turkana territory of Kenya. To the north lies the Republic of South Sudan and to the south are the Mt. Elgon highlands. In the west, Karamoja is bordered by the home territories of the Teso, Lango and Acholi ethnic communities. The mountain areas of Karamoja are inhabited by the Tepeth Teuso and Nyangwe (Kagan et al. 2010). The semi-arid lands of Karamoja are inhabited by pastoralist and agro-pastoralist communities. Rainfall in the region is variable, unpredictable and often sparse (Quam 1999). Rainfall totals vary (from around 500 to $800 \mathrm{~mm}$ ) within the sub-region with the few highlands generally receiving higher totals than much of the plains. Temperatures are generally high all year round. In the north and south and along the eastern escarpment are the forested mountainous areas, and in the west of the area (where the Labwor people inhabit the Abim district), the land is better watered with high vegetation cover of bushlands and woodlands.

The area is dominated by indigenous tropical grasses such as Themeda triandra, Heteropogon spp., Andropogon spp., Aristida spp., Eragrostis superba, Panicum maximum, Chloris gayana, Setaria spp., Brachiaria spp., Hyparrhenia rufa, Cenchrus ciliaris, Cynadon spp. and Hyperthelia spp. The overstorey is dominated by Acacia tree species such as Acacia tortilis, Acacia mellifera, Acacia etbaica, Acacia nilotica, Acacia brevispica, Acacia bussei and Acacia albida (Anderson and Robinson 2009; Nalule 2010). Owing to the spatial and temporal variability in rainfall and forage availability, the Karamoja pastoralists strategically move their animals to optimize utilization of various ecological niches subject to water availability and security (Grade et al. 2009).

\section{Land use/cover types in Karamoja}

Five land use/cover types were identified in the subregion, namely subsistence farmlands, woodlands, grasslands, thickets and shrublands, and lastly bushlands (Figure 2a, b,c,d). Table 1 below describes the characteristics of each land cover type.

\section{Methods}

\section{Herbaceous forage quantification}

In order to quantify the herbaceous and woody forage production in different land cover classes, ground measurements of above-ground biomass were conducted in study sites jointly identified by the community elders and herders. Selection of sampling plots targeted areas that were currently used for grazing. However, only the accessible sites and those secure from banditry and raiding at the time of the study were selected for sampling. Once the sites were identified, sampling plots for forage clipping, measuring $50 \times 40 \mathrm{~m}$ with four replications, were randomly established in each of the identified grazing land covers. In all the $50 \times 40 \mathrm{~m}$ plots, nested subplots were diagonally established from which forage was clipped. All the above-ground herbaceous plants, grasses, grass-like species, herbaceous legumes and other forbs collectively were clipped. In the woodlands, five plots of $5 \times$ $5 \mathrm{~m}$ established diagonally provided sampling sites, while in the thickets and shrubland, ten plots of $5 \times 5 \mathrm{~m}$ were utilised for forage clipping. In the grasslands, 20 plots of $1 \times$ $1 \mathrm{~m}$ were diagonally set up from where forage was clipped. The clipped herbaceous biomass was fresh weighed and a $0.5 \mathrm{~kg}$ proportion obtained for dry matter determination. Vegetation sampling was done during the dry, wet and transition seasons. Additionally, in each sampling plot, existing herbaceous and woody species were identified on-site by a field taxonomist. Specimens of species that could not be readily identified were collected using a plant press and taken to Makerere University for identification.

\section{Satellite data and image processing}

In quantifying land use and land cover change in Karamoja, the study made use of 27 years' time-series multi-spectral and multi-temporal Landsat TM and $\mathrm{ETM}+$ satellite imageries. The images obtained were generally cloud-free (less than $10 \%$ cloud cover) with a $30-\mathrm{m}$ resolution. Four scenes covering the sub-region were mosaiced (see Figure 3) in ERDAS IMAGINE 9.1 with the projection set at datum WGS 1984, UTM zone $36 \mathrm{~N}$ and Ellipsoid WGS 84. All the image sets utilised were acquired within a similar period (season) of the calendar year so as to minimize distortions associated with phenological variations between seasons. With reference to the 2009 land use/land cover map for Karamoja developed under KALIP, reconnaissance field 


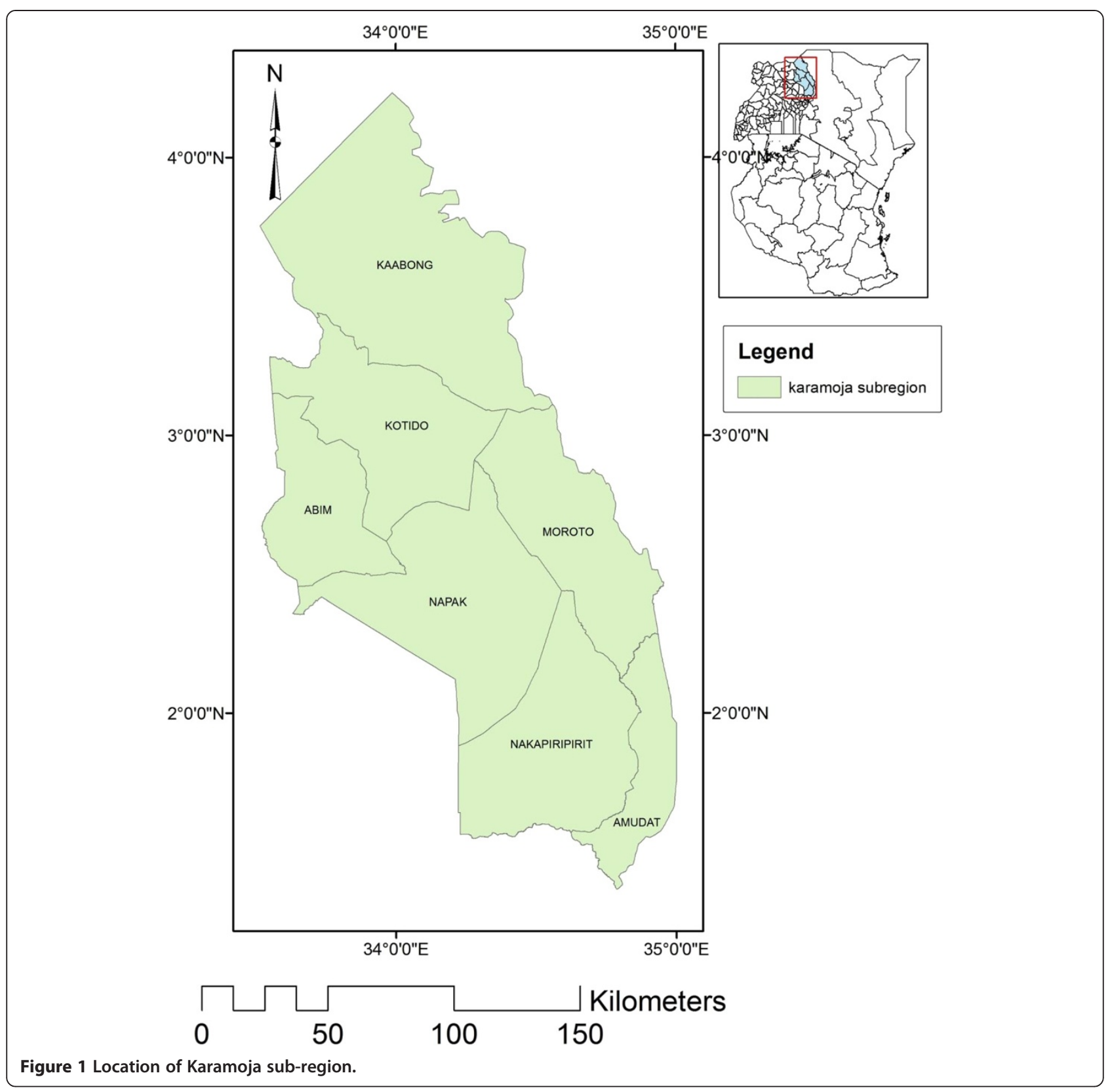

surveys were conducted from October 2012 to November 2013; Landsat TM and ETM+ images were interpreted and classified using unsupervised classification. A total of 465 ground truthing points were used to aid in the image classification and validation. Elders locally known as ikasuko and youth, referred to as karachuna in NgaKarimojong language, with detailed knowledge of the grazing landscapes provided additional information for image validation. In order to test the classification accuracy, we computed a confusion matrix/error matrix. Imagery processing and analysis were performed in ERDAS IMAGINE 9.1 and ArcGIS 10.1.

\section{Normalized Difference Vegetation Index data and processing}

The Normalized Difference Vegetation Index (NDVI) data obtained from the Moderate Resolution Imaging Spectoradiometer (MODIS) was obtained from the National Aeronautics and Space Administration (NASA; http://reverb. echo.nasa.gov/reverb/). MODIS NDVI was preferred due to its consistency, uniform coverage, minimal interferences and a high temporal (16-day) resolution. MODIS NDVI imagery was pre-processed in ERDAS IMAGINE 9.1. Subsequently, NDVI values were extracted for each plot where herbaceous biomass clipping was undertaken. The extraction was performed using the extraction tool embedded in the spatial analyst in ArcGIS 10.1. 

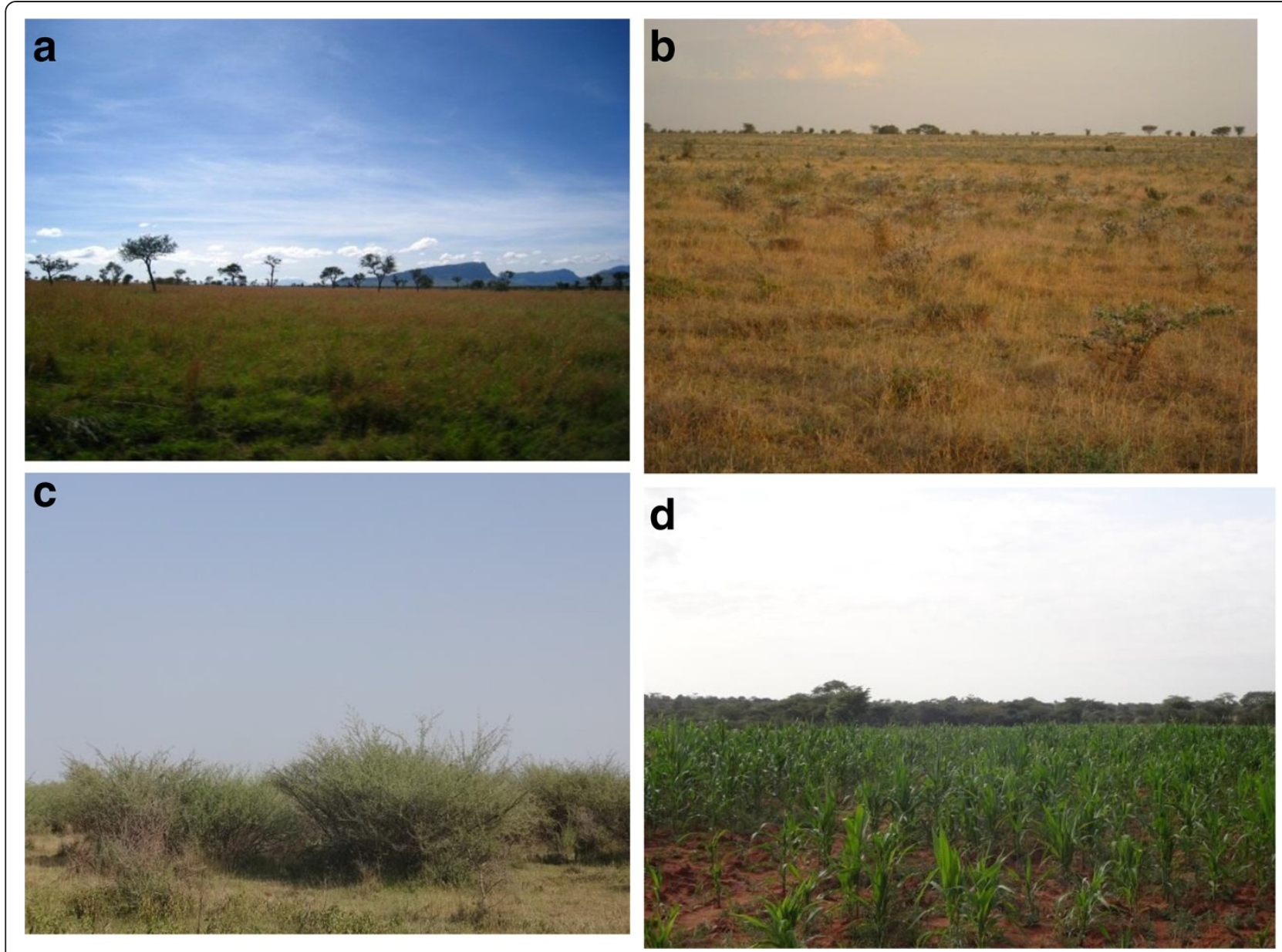

Figure 2 Land use/cover types. (a) Typical grassland dominated by Hyparrhenia rufa and Chloris pychnothrix in Karamoja as seen from Nakicument, Napak district. In the background are the Iriir mountains. (b) A thicket and shrubland as seen in Regen sub-county, Kotido district. The landscape is dominated by grasses such as Bracharia spp. and Hyparrhenia spp. grasses and thicket and shrub species such as Commiphora campestris, Cadaba farinosa and Acacia brevispica. (c) A bushland land cover near Lomogol dam in Kotido district (Acacia oerfota seen in the middle of the picture). (d) A maize garden adjacent to woodland land cover in Nabuin. The woodland is at the background of the photo.

\section{Data analysis}

Forage species analysis and determination of herbaceous forage quantity

Data on the identified herbaceous and woody species were collated and subjected to descriptive statistical analysis using Genstat 12.1 to generate a matrix of frequency of species and life forms for the different land cover classes in the study area. In order to determine the quantity of dry matter, herbaceous samples taken to the laboratory were oven-dried at $60^{\circ} \mathrm{C}$ until a constant weight. Following the Undersander et al. (1993) approach, dry matter was determined gravimetrically as the residue remaining after oven drying. The gravimetrical results of different sampling plots were pulled together by land cover type and averaged to obtain dry matter weight $(\mathrm{kg} / \mathrm{ha})$.

\section{Determining sources of herbaceous forage quantity variation}

In order to identify the sources of variation in the quantity of forage, we conducted a one-way analysis of variance (ANOVA). Mean quantity of forage by land cover type, location (district) and season were compared. Additionally, interactions between land cover and location (district), land cover and season, and season and district were tested using F-test statistic at 5\% significance level in Genstat 12.1.

\section{Determining land cover change matrix}

This study adopted Peng et al.'s (2008) approach (Equation 1) of determining land use/cover change. Land cover change matrix was computed by overlaying two land use/cover maps. Using this method, an overlay of two land cover maps $A_{i * i}$ and $B_{i * i}$ adheres to the map algebraic Equation 1 which is only functionally valid where land 
Table 1 Characteristics of land cover types in Karamoja (based on Thomas 1943; Allen et al. 2011)

\begin{tabular}{ll}
\hline Land use/cover type & Location \\
\hline Croplands & About 1 to 4 km away from the manyattas (homesteads). \\
& Traditionally, the largest cultivations are those around \\
& Kangole (now Napak district), west of Moroto (Nadunget \\
& sub-county), around Kotido (Panyangara and Nakapelimoru) \\
& and north of Toror hills (Thomas 1943). From Lorengdwat \\
& through to Southern Karamoja-Namalu area are dotted plots \\
& of croplands. Water deficits are a known challenge to the \\
& cropping estate \\
& Between four groups of hills, Moroto, Toror, Napak-Iriir \\
& (Figure 2a) and Lawor, there is a landscape of open \\
& grasslands. Grasslands also occur in the open plains of \\
& Nakaale in Amudat district after Tokora to the lower areas of \\
& Namalu through the broader plains of Moruajore and Pian \\
Grasslands & Upe game reserve and much of Lolachat in Nakapiripirit \\
& district. This stretch of grasslands follows a northward \\
& trending through Lolachat to Iriir and to the foot slopes of \\
& Opopwa hills north of Napak district where Themeda \\
& triandra, Bracharia brizantha, and Sporobolus pyrimidalis are \\
& dominant grasses (Thomas 1943)
\end{tabular}

Thickets and shrubland These are generally more dominant in Kotido (Figure 2b) district than anywhere else in the region. They also occur around Panyangara, Nakapelimoru and parts of Regen subcounty from areas of Lokadeli

Woodlands

Bushlands

cover classes are not in excess of 10 . After operationalizing the map algebraic function, a land cover change map is obtained. Thus, $C_{i * j}$ becomes the output that represents the type of land cover variation from time A to time B with the associated spatial dispersion. In this study, there are five land covers (i.e. grasslands, woodlands, thickets and shrublands, croplands and bushlands).

Generally tropical savanna-woodlands occurring in the south and west (Iririr), north west in the Labwor ranges (present day Abim district), central region around Mount Moroto, and far north to Mount Zulia area; from Nabuin (Figure 2d) through parts of Kamulasabala through to Acholchol in Nakapiripirit district; and areas around Moruita in Amudat district. Compared to all other districts in the sub-region, woodlands in Kotido are insignificant and those that exist occur mainly along river channels and a few major shrines (respected for traditional ceremonies)

Fringes of gardens, areas with a past history of grazing but with decreased grazing over the last 15 years and former abandoned kraals (old livestock enclosures). One can easily observe bushland land covers around Toror mounts, Lobel in Kotido district (Figure 2c). In Kaabong district, a wide spread beginning from around Lobunyet to the northeast trending parts of Nakimoru, Napararo, Kamion, Oropoi, Morungole and towards Pirre. In Moroto district, bushland can be observed after the Moroto River in the northeast trending to Lokisile, llokapel and after River Acholchol and towards the airstrip in Amudat district

\section{Description}

All land is dedicated to the production of cultivated crops. In Karamoja, these are principally open cultivated fields with sorghum as the main staple crop (Figure 2d). Trees (often thorny bushes, twigs and trees) are cleared during land opening. Once productivity has declined, the farmer either clears the adjacent land and/or shifts to another location. These farmlands are often located a few metres from the manyattas to about $4 \mathrm{~km}$ away

Land composed of annual, biennial and/or perennial selfseeding grasses. In Karamoja, these are natural grasses that include all the grass steppes and savannas in the east, grasslands of the broad valleys in the center and open grasslands of the plains in the south and west of generally grass steppes. Grasses such as Setaria holstii, Panicum meyerianum and Themeda triandra and the legume Clitoria ternatea can be found in these areas (Thomas 1943)

Land on which vegetation is dominated by low-growing woody plants having single to multiple stems arising at or near the base (Allen et al. 2011). In Karamoja, this landscape when looked at from a distance forms whitish carpeting (especially during the dry season) of thorny trees (generally of a low height of 1 to $3 \mathrm{~m}$ although the more mature trees may reach 5 to $6 \mathrm{~m}$ ) with short grasses at the base. These trees are generally Acacia species (e.g. Acacia drepanolobium, A. oerfota, A. kirkii) providing browse for ruminants
Land with a plant community which, in contrast to a typical forest, contains trees that are often small, characteristically short-boled (height ranges 5 to $20 \mathrm{~m}$ ) relative to their crown depth and form an open canopy only with the intervening area being occupied by shorter vegetation, commonly grass (Allen et al. 2011). In Karamoja, these areas are generally occupied by deciduous trees with a fair height level in the range of 5 to $12 \mathrm{~m}$ (Figure $2 \mathrm{~d}$ at the far background). Tree species such as Combretum binderianum and Bauchinia thoningii can be found in this land cover with interwoven Acacia and other plant forms including grasses that similarly occur in the grasslands

Land with $>15 \%$ to $20 \%$ bush or shrub cover and plant height ranging on average between 3 and $6 \mathrm{~m}$. In the Karamoja case, some bush and shrub vegetation form a Acacia oerfota, A. mellifera, and A. nilotica, and around Lorengdwat in Nakapiripirit district and Lokisile in Moroto district, there is a mix of Euphorbia prostrate, E. candlebrum and $E$. tirucalli. A slight variation exists in the southern bushlands which are relatively stable and even becoming woodlands in places, while the bushlands in Moroto and parts of Kotido are relatively young with aggressive tree species of Acacia oerfota and A. mellifera. These were mainly identified by the key informants as formerly heavily grazed areas with some having occurred in former croplands $\mathrm{V}$-shape spreading canopy (Figure 2c). It is dominated by 


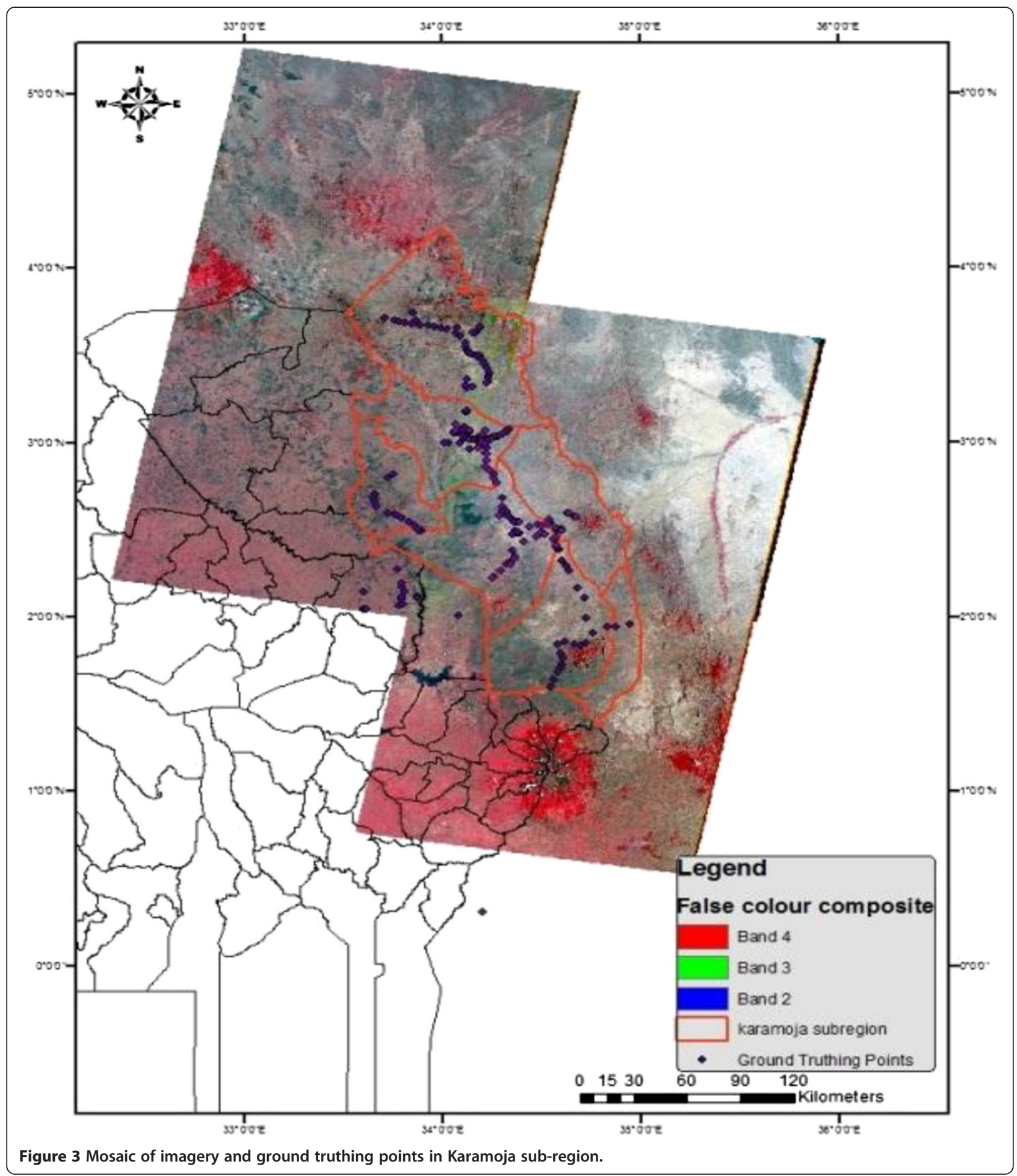

where $K_{1}$ is the land cover dynamic degree; this measures the change rate of the target land cover type. $U_{b}$ and $U_{a}$ are the area of the target land cover at the beginning and end of the study period, respectively, and $T$ is the study period in years. Land use and land cover change was assessed over three periods, namely 1986 and 2000 (14 years), 2000 to 2013 (13 years) and 1986 to 2013 (27 years).

\section{Determining the regional forage quantity}

The average weight ( $\mathrm{kg} / \mathrm{ha}$ ) of herbaceous biomass (both dry matter and wet weight) was multiplied by the total land 
area (ha) of respective land cover types to obtain the relative regional quantity of herbaceous forage by land cover type and season. Although clipping was not extensively conducted in the bushlands (for security reasons) and croplands, a few sites that provided a comparison value were available. In addition, the quantity of herbaceous biomass obtained from the bushlands compared quite well with the results of Ooro-Olang (1984) in southern Turkana, an area bordering the study region at Amudat district. The computation of herbaceous weight in the croplands revealed that it was $5 \%$ thickets and shrublands standing crop during the dry season. We assumed that during the wet season, all croplands were non-useable for livestock since they had been planted with crops.

\section{Determining the relationship between herbaceous forage quantity and NDVI}

In order to determine the relationship between herbaceous biomass and NDVI, the average NDVI values were derived from the plot-specific extractions. The extracted plot-specific NDVI values were matched with plot-specific wet weight herbaceous biomass quantity of each land cover type monitored. We then conducted a generalized linear regression using XL-STAT 2013.5 statistical package.

\section{Results}

\section{Herbaceous and woody forage plants in Karamoja}

In the thicket and shrubland land cover, there were 12 grass, 11 herb, 4 shrub, and 6 tree species respectively distributed in 13 families (Table 2). The herbs within the thicket and shrubland land cover type had the largest number of families. In the grasslands, 18 grass, 14 herb, 5 shrub and 7 tree species distributed in 20 families were observed. Like in the thickets and shrubland land cover type, herbs similarly had the largest number of families. On the other hand, the woodland land cover had 14 grass, 15 herb, 8 shrub and 13 tree species distributed in 26 families. Like all the other land covers, herbs had the largest number of families. Climbers and sedges were observed primarily in the thicket and shrubland land cover as well as in the woodland land cover.

The common grass species observed in most of the land covers included Pennisetum unisetum, Hyparrhenia diplandra, Hyparrhenia filipendula, Sporobolus festivus, Sporobolus stapfianus, Cyndon dactylon and Chloris pychnothrix. The distribution and occurrence of specific grasses in respect to each land cover type are presented in Additional file 1: Table S2c and d. Besides the variety of grass species, a range of herbs, shrubs and trees were also observed in the land covers. The common family observed in the thicket and shrublands was Capparaceae with a range of species including Maerua pseudopetalosa, Capparis tomentosa, Cadaba farinosa and Toddalia asiatica.
Table 2 Summary of number of species and families for plant types by land cover type in Karamoja

\begin{tabular}{lcc}
\hline $\begin{array}{l}\text { Land cover and } \\
\text { plant category }\end{array}$ & Number of species & Number of families \\
\hline Thickets and shrublands & 12 & 1 \\
Grass & 11 & 8 \\
Herb & 4 & 2 \\
Shrub & 6 & 2 \\
Tree & 1 & 1 \\
Climber & & \\
Grasslands & 18 & 1 \\
Grass & 14 & 12 \\
Herb & 5 & 3 \\
Shrub & 7 & 4 \\
Tree & & 1 \\
Woodlands & 14 & 10 \\
Grass & 15 & 7 \\
Herb & 8 & 8 \\
Shrub & 13 & 1 \\
Tree & 1 & \\
Sedge & & \\
\hline
\end{tabular}

However, Xanthium strumarium and Prosopis spp. alien species were also observed in the sub-region. The locals attributed its existence to the distribution of relief food and seeds. They also noted that it was particularly dangerous to the small ruminants (goats and sheep) as it caused lumpy skin and wounds. Further, during the field surveys $X$. strumarium L. was observed to be widespread around the manyattas (homesteads), along roadsides and cultivated farmlands. A number of Acacia tree species that provide browse were also observed including Acacia kirkii, A. drepanolobium, A. brevispica, A. tortilis, A. nilotica, A. sieberiana, $A$. mellifera and $A$. gerrardii (see Additional file 1: Table S2c and d).

\section{Quantity of forage in different land use/cover types}

The results revealed that during the wet season, woodlands had the highest herbaceous biomass quantity of $1,342.5 \pm 104.5 \mathrm{~kg} /$ ha followed by grasslands with $857.5 \pm$ $29.4 \mathrm{~kg} / \mathrm{ha}$, bushlands with $825 \pm 50.2 \mathrm{~kg} / \mathrm{ha}$ and thickets and shrublands with $501 \pm 43.9 \mathrm{~kg} / \mathrm{ha}$ (Figure 4). Similarly, during the dry season $542.5 \pm 57.6 \mathrm{~kg} / \mathrm{ha}$ was realized in the woodlands, $273 \pm 6.4 \mathrm{~kg} / \mathrm{ha}, 305.8 \pm 24 \mathrm{~kg} / \mathrm{ha}$ in the bushlands, $140 \pm 9.2 \mathrm{~kg} / \mathrm{ha}$ in the grasslands and thickets and shrublands respectively (Figure 4). This represented a $59.6 \%, 62.9 \%, 68.2 \%$ and $72.1 \%$ reduction between the wet and dry seasons in above-ground biomass in the woodlands, grasslands, bushlands and thicket and shrublands, respectively. 


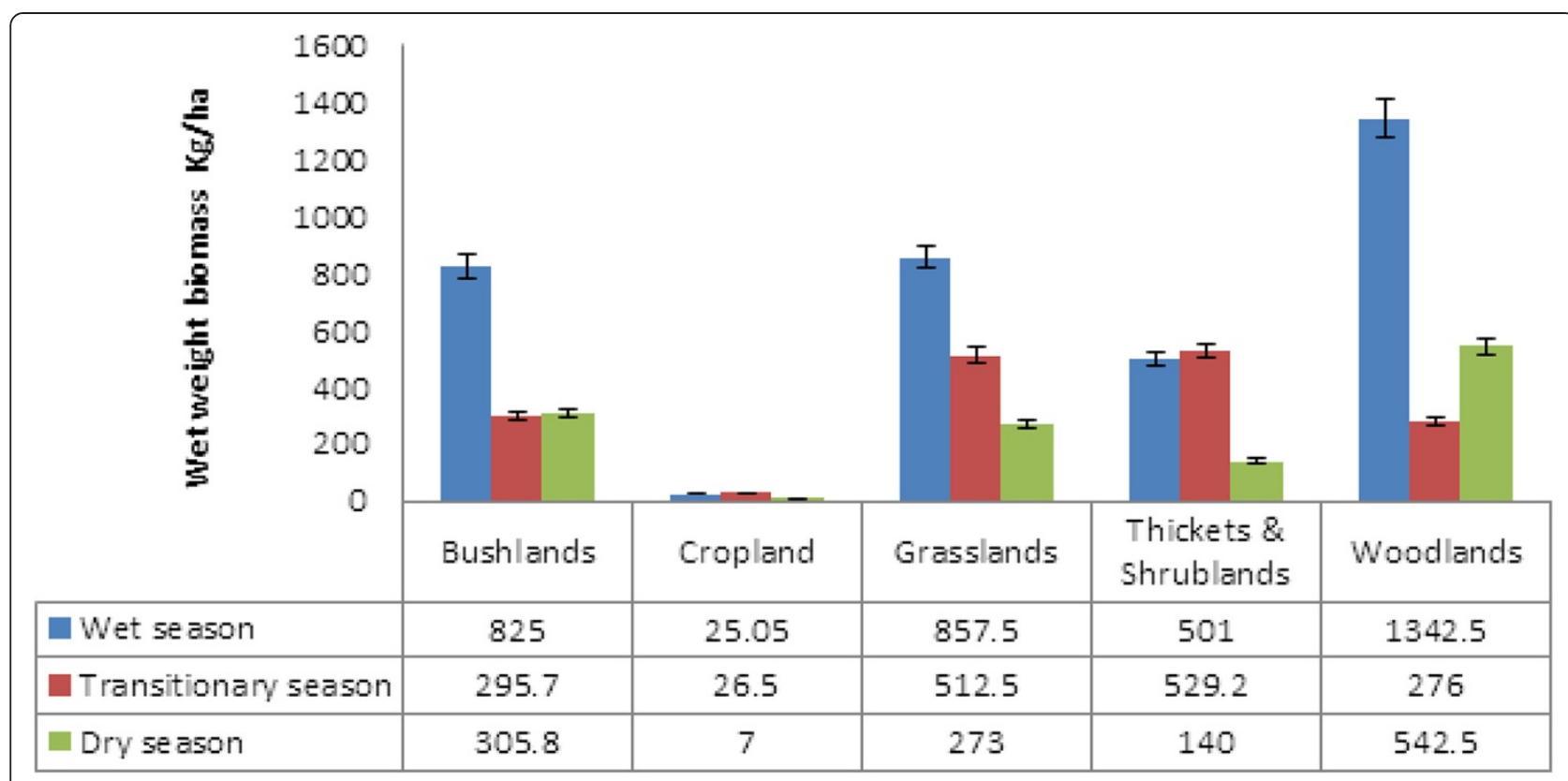

Figure 4 Wet weight biomass in different land use/cover biomes for all seasons.

On the other hand, results from the transitionary season assessment revealed that the thickets and shrublands had the highest wet weight biomass of $529.2 \mathrm{~kg} / \mathrm{ha}$ which was slightly higher than that observed during the wet season (Figure 4). This could be attributed to the fact that thickets and shrublands are less grazed by cattle during the dry season which are instead mainly grazed by sheep and goats. This is because most of the cattle population (apart from the milking herd) is often taken to the distant dry season grazing grounds. Secondly, the dominance of woody shrubs in the thickets and shrublands makes it a preferred grazing landscape for sheep and goats than cattle. As such, grasses have the opportunity to flourish as goats and sheep have higher preference for browse than herbaceous biomass.

Grasslands revealed a $512.5 \mathrm{~kg} / \mathrm{ha}$ wet weight biomass in the transition season which was a reduction from the wet season average of $857.5 \pm 29.4 \mathrm{~kg} / \mathrm{ha}$ (Figure 4). The pattern was not any different in the woodlands, with only $276 \mathrm{~kg} / \mathrm{ha}$ of wet weight biomass realized. This was slightly lower than the dry season average of $542.5 \pm 57.6 \mathrm{~kg} / \mathrm{ha}$ (Figure 4). This could be attributed to fire and croplands that affected some of the monitoring plots.

In terms of dry matter (Figure 5), woodlands had 42.3 and $31.7 \mathrm{~kg} / \mathrm{ha}$ during the wet and dry seasons, respectively. This represented $3.2 \%$ and $5.8 \%$ of the standing crop available as dry matter in the woodlands. On the other hand, grasslands had 42.6 and $10.7 \mathrm{~kg} / \mathrm{ha}$ of dry matter during the wet and dry seasons accordingly, indicating that $4.9 \%$ and $3.9 \%$ of the wet weight biomass could be available as dry matter. In the thickets and shrublands, the situation was not any different, with 26.8 and $9.6 \mathrm{~kg} / \mathrm{ha}$ obtained during the wet and dry seasons, respectively, which were equivalent to $5.3 \%$ and $6.9 \%$ of the wet weight biomass available as dry matter (Figure 5). In all seasons, thicket and shrubland vegetation had relatively lower quantities of dry matter. However, it had higher dry matter rates of recovery at $5.3 \%$ and $6.9 \%$ for wet and dry seasons, respectively. The patterns in thickets and shrublands could be attributed to the fact that there is lower grass and herbaceous plant cover due to the predominance of thorny twigs and plants that provide browse. Secondly, grass and other herbaceous plants within the thickets and shrublands tended to be hardy compared to those occurring in the grasslands and woodlands. Results from the transitionary season revealed that thickets and shrublands had the highest dry matter of $22.9 \pm 9.6 \mathrm{~kg} / \mathrm{ha}$, followed by grasslands, bushlands and woodlands. Not surprising, croplands performed poorly in terms of dry matter just as they did in determinations of wet weight biomass (Figures 4 and 5).

\section{Sources of variation in forage quantity}

Table 3 shows the sources of variation in the quantity of forage in Karamoja sub-region. Results showed a highly significant $(p \leq 0.05)$ influence of land cover-land cover type on the quantity of dry matter biomass recovered as well as the quantity of the fresh weight forage in a given location (Table 3). A significant $(p \leq 0.05)$ variation in fresh weight forage and dry matter biomass between the districts of Moroto (merged with Napak) and Kotido existed. Furthermore, season had a significant influence 


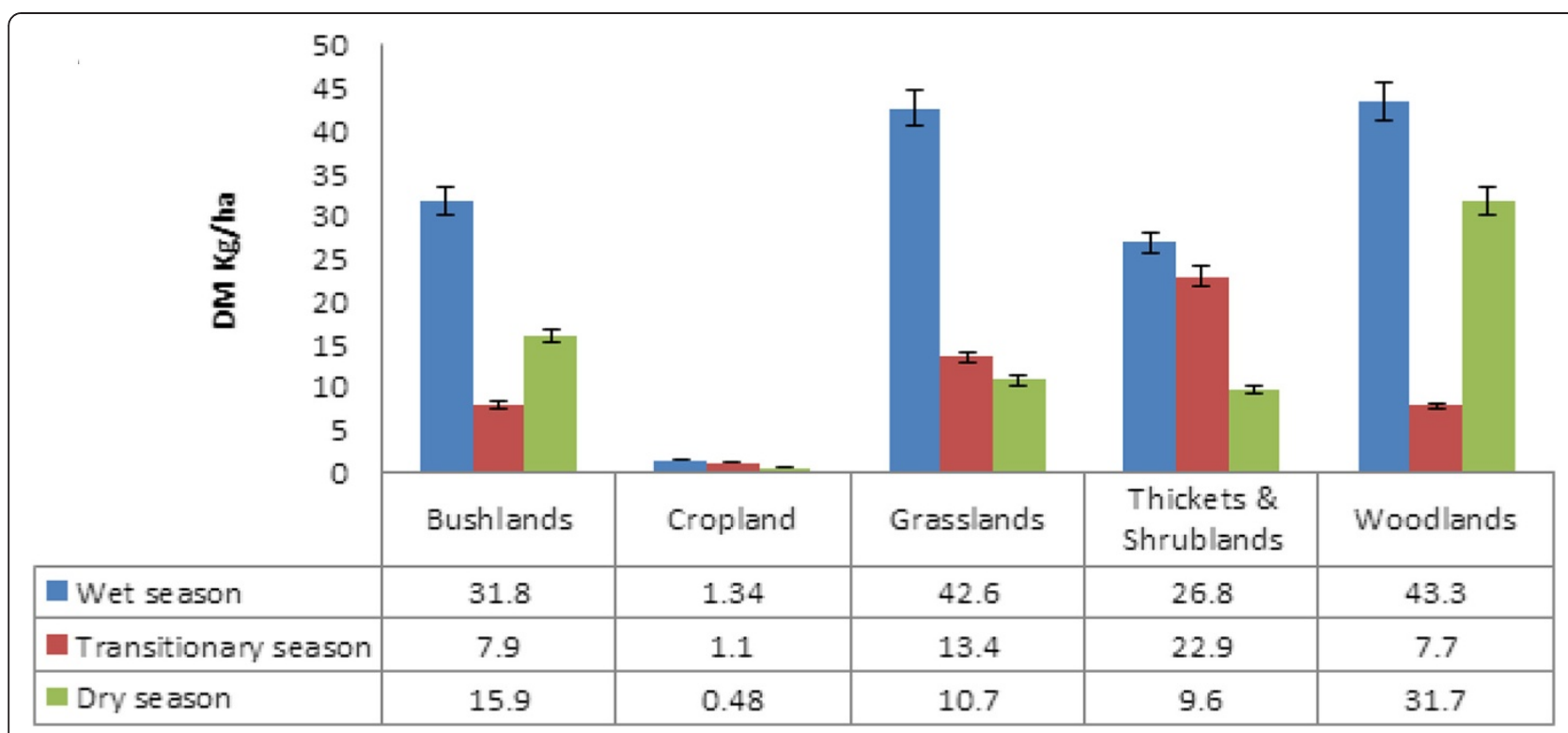

Figure 5 Dry matter from different land use/cover biomes for all seasons.

on the variation of fresh weight forage and dry matter recovered from the various land covers in the sub-region (Table 3). Further, results showed that there was a significant $(p \leq 0.05)$ interaction between season and land cover types as well as between district and season (Table 3 ). This suggests that considerable heterogeneity exists within the sub-region.

Pattern of land use/cover change in Karamoja (1986 to 2013) During the last 27 years, there have been significant changes in land use/cover of the grazing lands of Karamoja sub-region (Figure 6a,b,c). The trend patterns are presented in Table 4. Results show that in 1986, grasslands (75\%) dominated the region. Croplands only covered $0.3 \%$ of the land area (Table 4). By 2000, bushlands had increased by $2.2 \%$ to $15 \%$. Similarly, thickets and shrublands experienced a fivefold increase. On the other hand, grasslands experienced a decline by $1.6 \%$ to $74.2 \%$ of the land area. This pattern was also observed in the woodlands and croplands. Woodland coverage in 2000 decreased by $5.3 \%$, while croplands decreased by $0.24 \%$ of the 1986 level. The

Table 3 Sources of variation in forage in Karamoja sub-region

\begin{tabular}{lccccc}
\hline Source of variation & $\boldsymbol{d f}$ & $\mathbf{s s}$ & $\mathbf{~ m s}$ & $\mathbf{v r}$ & $\boldsymbol{F ~ p r}$ \\
\hline Land cover type & 2 & $2,854.2$ & $1,427.1$ & 10.94 & $<0.001$ \\
District only & 1 & $2,573.6$ & $2,573.6$ & 19.73 & $<0.001$ \\
Season & 1 & $4,754.6$ & $4,754.6$ & 36.45 & $<0.001$ \\
Land cover $\times$ District & 2 & 310.8 & 155.4 & 1.19 & 0.318 \\
Land cover $\times$ Season & 2 & 960.5 & 480.3 & 3.68 & 0.038 \\
District $\times$ Season & 1 & $7,919.5$ & $7,919.5$ & 60.71 & $<0.001$ \\
\hline
\end{tabular}

Results are based on $F$-test. $d f$, degree of freedom; ss, sums of squares; ms, means of squares; vr, variance; $F$ pr, probability. period between 2000 and 2013 also recorded continued increase in the cover of bushland vegetation to $25 \%$ which represents a 10\% increase in cover between 1986 and 2013. Surprisingly, woodland land cover experienced a recovery to $2.7 \%$, indicating a $1.4 \%$ increase. However, in terms of change, the period from 2000 to 2013 revealed a nearly tenfold increase in croplands. This could be attributed to increased advocacy and promotion for cropping by the Government of Uganda and development partners through provision of seeds and tractors. On the other hand, grasslands continued to experience a decline, falling to $66.0 \%$ which represents an $8.2 \%$ decrease. Likewise, thickets and shrublands decreased to $5.8 \%$ representing a $0.9 \%$ decline (Table 2). When the confusion/error matrix was computed, it showed an overall land cover change classification accuracy of $82.6 \%$ (producer's accuracy) and $75.3 \%$ user's accuracy.

\section{Land use/cover change matrix 1986 to 2013}

Tables 5, 6 and 7 present the process of land use/cover change within the land covers in Karamoja sub-region from 1986 to 2013. Three change phases are presented, the first from 1986 to 2000, the second from 2000 to 2013 and the third from 1986 to 2013. Results in Table 5 (1986 to 2000) reveal that much of the woodlands changed to grasslands. During the focus group discussions on the change history, participants noted that the rapid conversion of woodlands to grasslands during this period was associated with two factors: first, the livestock numbers increased rapidly because herds from neighbouring regions of Teso, Lango, Acholi and Sebei were routinely raided (This issue was only clarified by a former Karachuna 
Table 4 Land use/cover change in Karamoja sub-region

\begin{tabular}{|c|c|c|c|c|c|c|}
\hline \multirow[t]{2}{*}{ Land use/cover types } & \multicolumn{2}{|c|}{1986} & \multicolumn{2}{|c|}{2000} & \multicolumn{2}{|c|}{2013} \\
\hline & Area (ha) & $\%$ area & Area (ha) & $\%$ area & Area (ha) & $\%$ area \\
\hline Bushlands & $352,948.3$ & 12.8 & $415,175.9$ & 15.0 & $689,614.0$ & 25.0 \\
\hline Croplands & $7,520.7$ & 0.3 & $1,695.5$ & 0.06 & $15,686.4$ & 0.6 \\
\hline Grasslands & $2,093,308.1$ & 75.8 & $2,047,648$ & 74.2 & $1,820,488.6$ & 66.0 \\
\hline Thickets and shrublands & $123,996.2$ & 4.5 & $259,863.8$ & 9.4 & $159,841.5$ & 5.8 \\
\hline Woodlands & $182,576.8$ & 6.6 & $35,971.1$ & 1.3 & $74,730.8$ & 2.7 \\
\hline Total & $2,760,350.2$ & 100 & & 100 & & 100 \\
\hline
\end{tabular}

(youth) who participated in such raids, who is now a serving para-military providing security in the kraals.); second, rains were consistently poor during this period. As such, grazing intensity increased in woodlands. Most of the bushlands changed to grasslands. Bushlands to croplands experienced a marginal change. It was also observed that $36 \%$ of the grasslands converted to bushlands during the same period. Meanwhile, about half of the thickets and shrublands converted to grasslands, and about half of croplands converted to thickets and shrublands. There was no transformation of croplands to woodlands during this period.

Table 6 presents the land use/cover change patterns for 2000 to 2013. During this period, a considerable proportion of woodlands (46.6\%) remained unchanged. This could be attributed to the fact that most of the woodlands that are now in existence occur in the highlands and are thus relatively inaccessible to the local communities. However, most of the woodlands were converted to bushlands (39.5\%). These are probably the woodlands in the low-lying areas preferred for their perceived fertility and 'soil coolness' (as indicated by the local community during focus group discussions). A further $11.3 \%$ of the woodlands were converted to grasslands, $1.6 \%$ to thickets and shrublands and $1.1 \%$ to croplands. In the same period, $31.1 \%$ of the bushlands were converted to grasslands compared to $47.5 \%$ of the grasslands that converted to bushlands. This relatively greater increase of bushlands in grassland areas could be attributed to reduced grazing patterns in some locations.

In Figure 6c, it is shown that there was a rapid gain in bushlands in the northwestern (Abim district and Kaabong district) and the southern (Nakapiripirit and Amudat districts) parts of the study area. Abim district during this period (late 1990s to mid-2000s) experienced civil unrest orchestrated by the Lord's Resistance Army (LRA), and this affected the normal grazing calendar allowing the bushes to flourish. On the other hand, livestock rustling prohibited widespread utilization of the southern rangelands which allowed bushes to encroach in the formerly open grasslands. It is also observable that $43.6 \%$ of the croplands reverted to bushlands, $15.9 \%$ to grasslands and $29.3 \%$ to thickets and shrublands. Only $9.9 \%$ of the croplands remained unchanged. This result has confirmed what was observed during the ground truthing exercise in which most of the former croplands were being colonized by bushes as well as the prevalence of thicket and shrubland vegetation on abandoned cropland sites.

Table 7 portrays the change in land use/cover between land cover units from 1986 to 2013. With only $1.3 \%$ of the woodlands remaining unchanged, the data show that over the last 27 years, $98.7 \%$ of the woodlands have undergone conversion to one or more land cover type. Thus, woodlands converted to bushlands, grasslands, thickets and shrublands and croplands, respectively (Table 7). Vegetation clearance for charcoal (Figure 7) has rapidly grown in the recent past in Karamoja sub-region, and the traditional demand for wood for constructing manyattas (homesteads) with defense walls could have contributed to the disappearance of woodlands in the region. This study also reveals that from 1986 to 2013, bushlands converted to woodlands, grasslands, thickets and shrublands and croplands at varying levels (Table 7). The grassland land cover experienced the greatest conversion to bushlands by almost sixfold and woodlands by about twofold. It is also observable that some croplands reverted to grasslands (42.9\%) and to thickets and shrublands (35.8\%).

\section{Sub-regional quantity of forage during 2013}

The extrapolated results of wet weight biomass show that the grasslands had the highest potential quantity of biomass in both wet and dry seasons within the subregion study area, estimated at 1,561.1 and 210.9 million kilograms, respectively. This is not surprising given that grasslands occupy the largest land area in the sub-region as indicated from the land use/cover results. This was followed by bushlands, woodlands, thickets and shrublands and cropland areas (Figure 8). The pattern of forage quantity revealed by this extrapolation is largely influenced by the extent of land area occupied by a 


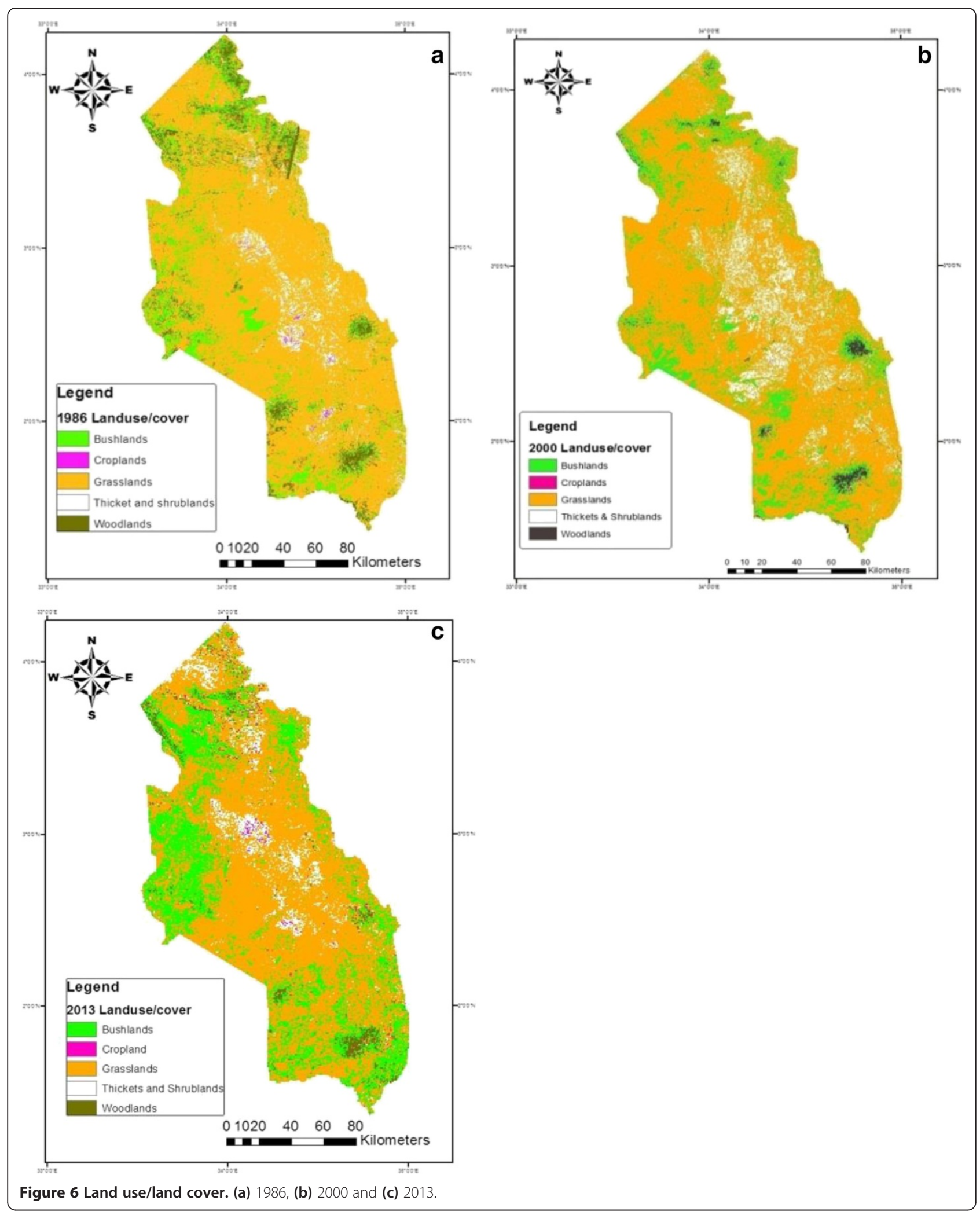


Table 5 Land use/cover change matrix (1986 to 2000)

\begin{tabular}{|c|c|c|c|c|c|c|}
\hline \multirow{2}{*}{$\begin{array}{l}\text { Land use/cover types } \\
\text { in } 1986\end{array}$} & \multicolumn{6}{|c|}{ Land use/cover types in 2000} \\
\hline & Woodlands & Bushlands & Grasslands & Thickets and shrublands & Croplands & Total \\
\hline Woodlands & 0.2 & 11.9 & 78.5 & 9.4 & 0.0 & 100 \\
\hline Bushlands & 2.0 & 30.2 & 66.2 & 1.5 & 0.1 & 100 \\
\hline Grasslands & 14.0 & 36.0 & 48.1 & 1.5 & 0.4 & 100 \\
\hline Thickets and shrublands & 0.1 & 3.4 & 52.6 & 43.7 & 0.2 & 100 \\
\hline Croplands & 0.0 & 1.7 & 44.0 & 51.7 & 2.5 & 100 \\
\hline
\end{tabular}

The figures marked in italics indicate the unchanged percent area during the period. The direction when making the table interpretation is left to right.

particular land use/cover type. In this respect, grasslands are the most important grazing land covers particularly for cattle in the sub-region in both the wet and dry seasons. Thickets and shrublands revealed a relatively higher quantity of wet weight biomass; however, this land cover is mainly used for grazing sheep, goats and some calves.

Relationship between NDVI and herbaceous forage quantity During the wet season, sub-regional average NDVI was $0.46 \pm 0.09$. With regards to land cover, woodlands had an average NDVI of $0.53 \pm 0.09$, grasslands $0.49 \pm 0.07$, thickets and shrublands $0.40 \pm 0.04$, croplands/croplands $0.30 \pm 0.00$ and bushlands $0.52 \pm 0.08$. On the other hand, the sub-regional average NDVI during the dry season was $0.41 \pm 0.11$. There was however slight variation at land cover type level (Figure 9). For example, a slightly higher average NDVI was observed in bushlands $(0.51 \pm 0.05)$ during the dry season. This was followed by woodlands $(0.49 \pm 0.08)$ and grasslands $(0.45 \pm 0.09)$. Further, a $0.31 \pm 0.05$ and $0.28 \pm 0.0$ average NDVI was observed in the thickets and shrublands and croplands, respectively, during the dry season. The relatively high NDVI in the bushlands can be explained by luxuriant growth of woody vegetation within this land cover type. A remarkably high average NDVI $(0.50 \pm 0.11)$ was observed during the transitionary season (Figure 9). In this season, woodlands had an average NDVI of $0.65 \pm 0.07$, grasslands $0.51 \pm 0.08$, thickets and shrublands $0.43 \pm 0.07$, bushlands $052 \pm$ 0.07 and croplands $0.38 \pm 0.07$. Thus, as expected, all land cover types reflected a progressive improvement in vegetation greenness from 2012/2013 dry season to
2013/2014 transition season (Figure 9). During the monitoring period, rainfall withdrawal occurred around May before the June peak was reached. However, rainfall later resumed intermittently between August and October leading to relatively high vegetation vigour observed until early November.

There is generally a strong correlation between aboveground wet weight biomass and NDVI, with $R^{2}$ varying between 0.62 and 0.98 (Additional file 2: Table S8). The strength of the relationship varied from one location to another, with the season and land use/cover types. The strength of the relationship was highest for Moroto and the least at the sub-regional level. During the dry season, the grasslands, thickets and shrublands as well as the woodlands of Kotido showed a very strong relationship with NDVI. On the other hand, the few pockets of woodlands in the area generally provide a distinctive NDVI signature from the rest of the land cover types with a very high $\left(R^{2}=0.98\right)$ biomass/NDVI relationship. Similarly, the grasslands of Napak also showed a very high biomass/NDVI relationship $\left(R^{2}=0.878\right)$. During the wet season, all land cover types (i.e. grasslands, woodlands and thickets and shrublands) showed a very high biomass/NDVI relationship. Grasslands and woodlands in Moroto had relatively low rates of change during the wet season. During the transitionary season, the strength of the relationship was relatively lower in Moroto and the sub-region compared to other locations. Differentiated positive gradient of change was observed for all sites and land cover types. It ranged from 0.0015 (woodland in Moroto) to 0.1422 (grassland at subregional level).

Table 6 Land use/cover change matrix (2000 to 2013)

\begin{tabular}{|c|c|c|c|c|c|c|}
\hline \multirow{2}{*}{$\begin{array}{l}\text { Land use/cover types } \\
2000\end{array}$} & \multicolumn{6}{|c|}{ Land use/cover types 2013} \\
\hline & Woodlands & Bushlands & Grasslands & Thickets and shrublands & Croplands & Total \\
\hline Woodlands & 46.6 & 39.5 & 11.3 & 1.6 & 1.1 & 100 \\
\hline Bushlands & 6.6 & 60.1 & 31.1 & 1.7 & 0.5 & 100 \\
\hline Grasslands & 1.4 & 47.5 & 45.9 & 4.8 & 0.4 & 100 \\
\hline Thickets and shrublands & 0.5 & 9.6 & 66.7 & 21.4 & 1.8 & 100 \\
\hline Croplands & 1.3 & 43.6 & 15.9 & 29.3 & 9.9 & 100 \\
\hline
\end{tabular}

The figures marked in italics indicate the unchanged percent area during the period. The direction when making the table interpretation is left to right. 
Table 7 Land use/cover change matrix (1986 to 2013)

\begin{tabular}{|c|c|c|c|c|c|c|}
\hline \multirow{2}{*}{$\begin{array}{l}\text { Land use/cover types } \\
1986\end{array}$} & \multicolumn{6}{|c|}{ Land use/cover types 2013} \\
\hline & Woodlands & Bushlands & Grasslands & Thickets and shrublands & Croplands & Total \\
\hline Woodlands & 1.3 & 44.1 & 49.1 & 5.3 & 0.3 & 100 \\
\hline Bushlands & 5.3 & 60.6 & 31.4 & 2.1 & 0.6 & 100 \\
\hline Grasslands & 16.1 & 59.3 & 21.1 & 2.4 & 1.0 & 100 \\
\hline Thickets and shrublands & 0.3 & 12.6 & 53.2 & 30.3 & 3.6 & 100 \\
\hline Croplands & 0.1 & 7.2 & 42.9 & 35.8 & 14.0 & 100 \\
\hline
\end{tabular}

The figures marked in italics indicate the unchanged percent area during the period. The direction when making the table interpretation is left to right.

\section{Discussion}

\section{Herbaceous and woody forage plant species}

The Karamoja land cover types are dominated by annual grasses that provide a diversity of forage for livestock in the sub-region. The relatively large number of herbaceous and woody browse forage species observed in the sub-region can be explained by the mobile livestock herding practiced by the Karamoja cluster (e.g. Karamojong, Uganda; Toposa, South Sudan; Turkana, Kenya; and Nyangatom, Ethiopia). Some of the grasses (e.g. Digitaria spp. and Eragrostis spp.) that were observed in this study have previously been documented in neighbouring Turkana as preferred species (Lusigi et al. 1984). The presence of such species could perhaps explain the continued grazing by the Turkana in the Uganda territory, besides their search for water during the dry season. Herbivore grazing in the rangeland ecosystems promotes growth of grasses, as well as dispersal and fecundity of seeds (Crawley 1983; Jeltsch et al. 1998; Best and Arcese 2009; Notenbaert et al. 2012); this appears to be the case in the current study area. Additionally, some of the browse species such as Acacia mellifera, A. brevispica, Euphorbia tirucalli and Prosopis juliflora were attributed by Karamojong pastoralists to the Turkana as responsible for their dispersal such as in Kayelein in Kotido district and Lokisile and Kobebe areas in Moroto district. These woody plants are important forage plants among the Turkana (Ooro-Olang 1984; Barrow 1988); however, A. mellifera is notorious for bush encroachment. It is vital to note that a considerable number of grass species documented in this study have also been observed in other semi-arid and savannah ecosystems, for example in Kaliro, Uganda (Tabuti and Lye 2009), in Senegal (Fensholt et al. 2004) and generally in the Sahel (Le Houerou 1980). This indicates the adaptability of such species to semi-arid ecosystems. However, there was a conspicuous absence of leguminous plants in most of the land cover types. Limited availability of leguminous forage plants in the rangelands has been observed to limit livestock growth, meat and milk yield from cattle, owing to crude protein and mineral limitations (Dzowela et al. 1997). This could therefore explain the outcry by the locals that there is no longer enough milk in the manyattas (homesteads).

\section{Quantity of forage at land use/land cover and sub-regional level}

The quantity of forage in the land covers of Karamoja documented in this study is generally within the range of those observed in other studies in tropical Africa such as over east and the Horn of Africa, (Angerer 2008), in Turkana, Kenya (Ooro-Olang 1984) and in the Sahelian rangelands of Senegal (Miehe et al. 2010. However, this study's results are considerably lower than those observed in commercially managed temperate climate grassland pastures such as in western Canada (Iwaasa et al. 2012). This study has also been able to document inherent variation in the quantity of forage that exists between different land covers, seasons and locations in Karamoja sub-region. The differences between wet and dry season forage quantity are attributable to variation in rainfall over the seasons. In semi-arid areas of Chad and Cameroon, Awa et al. (2002) noted that forage quantity is directly related to rainfall. This appears to be a similar situation in the Karamoja rangelands. However, this pattern reveals the major reason for mobile livestock grazing practices practised in the sub-region. In fact, the decline in wet weight forage quantity around the transitionary season (between August and November) provides a good rationale for pastoral mobility. Informal interviews with herders during the monitoring period revealed that these patterns in vegetation performance trigger scouting for grazing grounds and preparation for dry season movement. This study has also shown that grasslands have relatively lower yields compared to woodlands. However, because of their expansive nature in the region, they form the major grazing grounds. Secondly, grasslands in the region limited encumbrances to livestock during grazing because they have a relatively high grass cover compared to the tree cover (see Figure 2a). Thirdly, grasslands have generally been observed to have more nutritious and palatable forage (Ooro-Olang 1984; Reid et al. 2005), though some tree species can provide browse for livestock, including nutritious pods (Gambiza et al. 2010). 

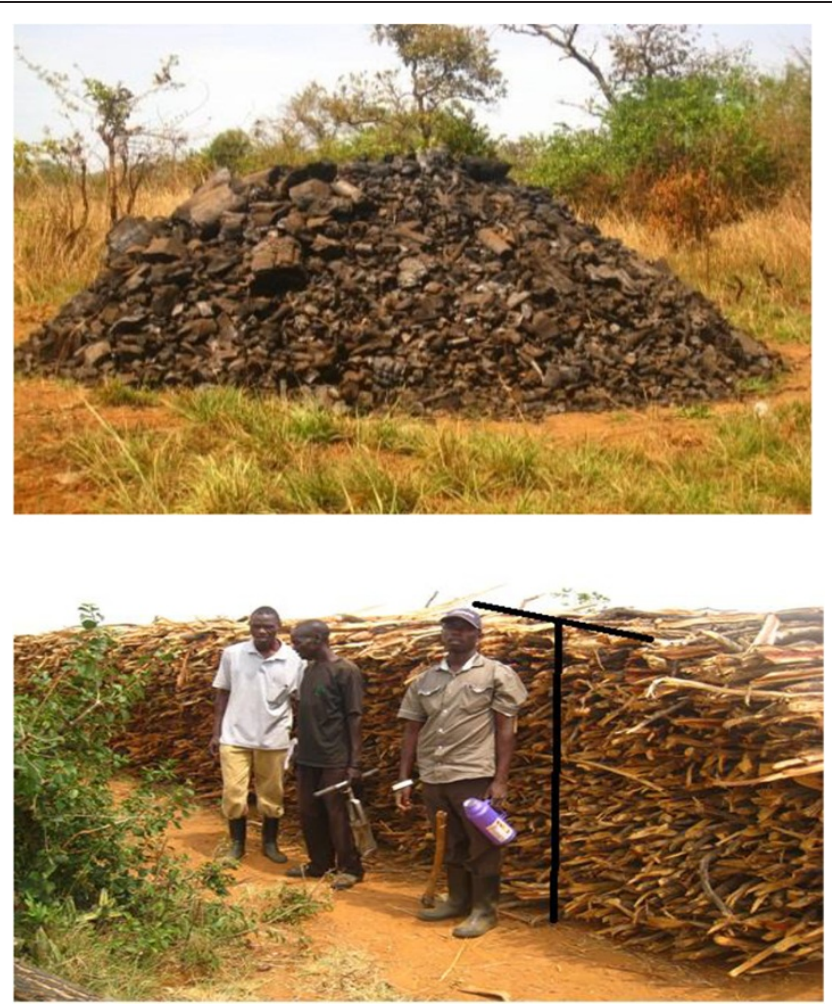

Figure $7 \mathrm{~A}$ heap of charcoal and firewood in Abim and Kotido districts.A heap of charcoal and firewood in Abim and Kotido districts.

The variations in quantity of both wet weight and dry matter biomass documented in this study are diverse. In the results, we have already seen that this pattern is linked to the type of land cover, location (district), seasonality and the interaction between land cover and district, land cover and season, and district and season. The seasonal variability of forage quantity has been documented elsewhere, for example in Cameroon and Chad (Awa et al. 2002), in the Sahelian flood plains (Scholte and Brouwer 2008) and South

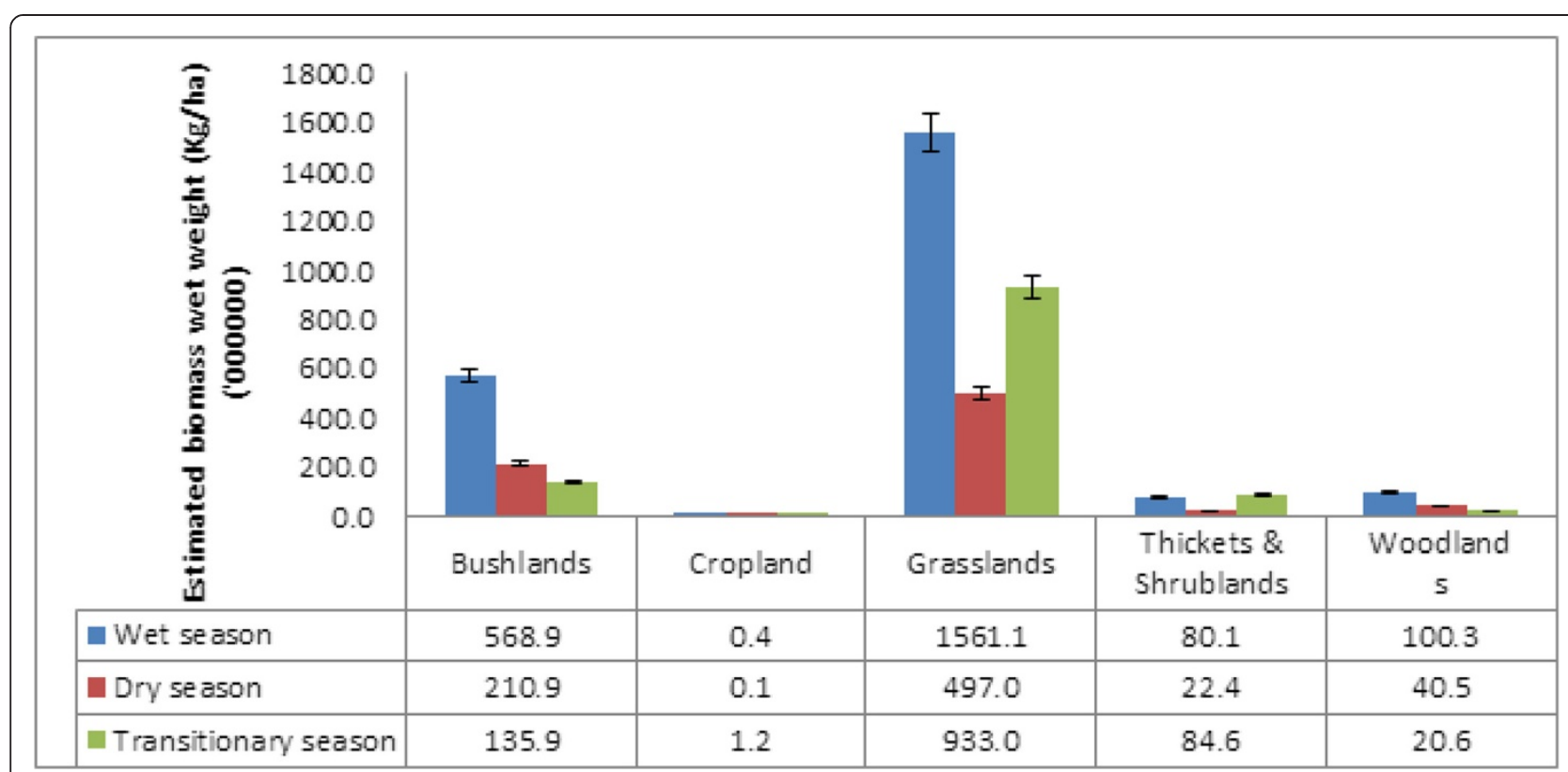

Figure 8 Extrapolated estimate of wet weight biomass in 2013. 


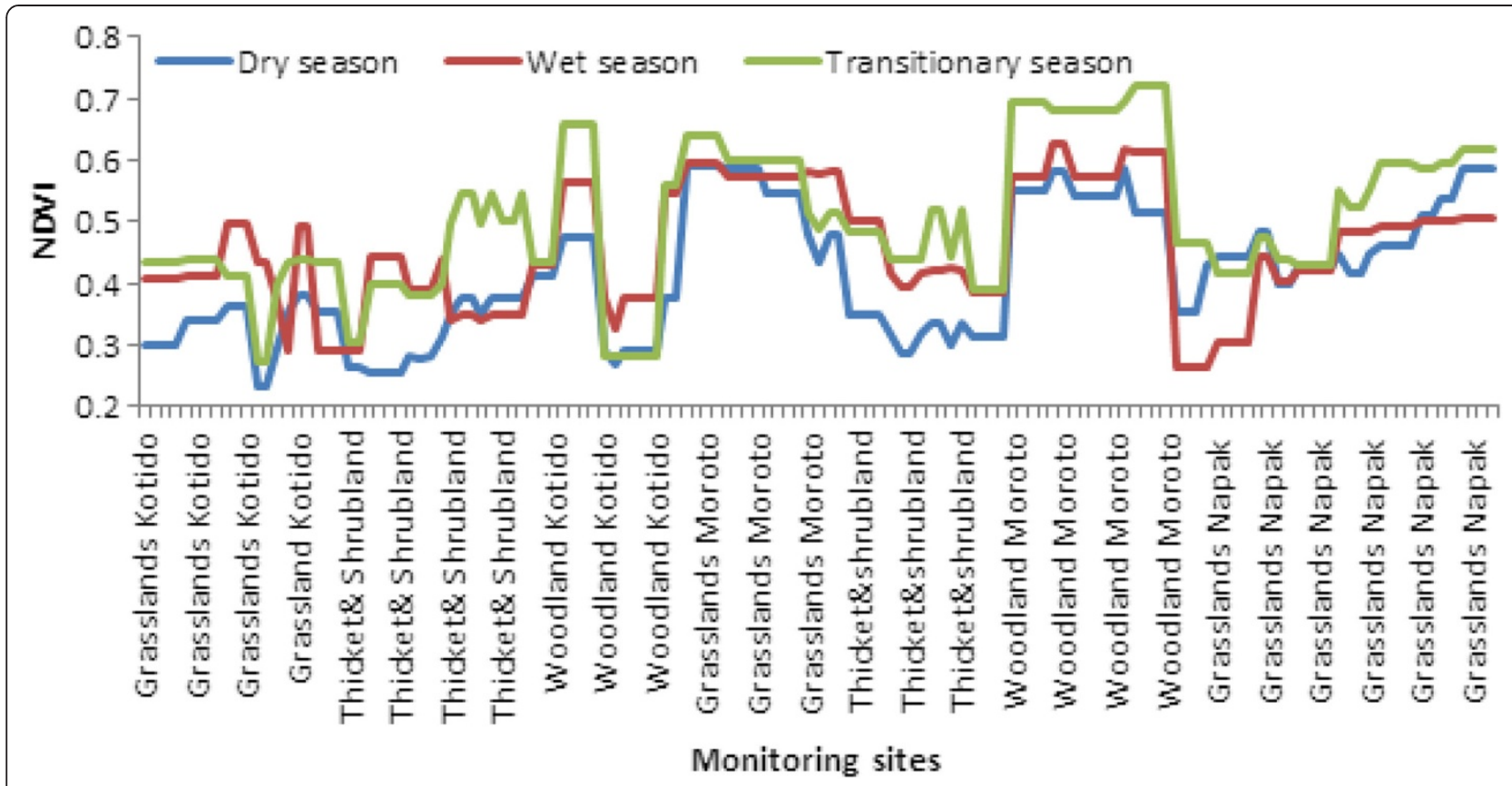

Figure 9 Pattern of NDVI in the monitoring sites.

Darfur state, Sudan (Abusuwar and Ahmed 2010). Seasonality also influences forage quantity due to its control on moisture availability which in turn influences vegetation growth. Karamoja sub-region is therefore not an exception. The differences existing in quantity of forage from different land covers are in part a result of existing heterogeneity. Heterogeneity in semi-arid regions is associated with variability in rainfall patterns (Augustine 2010; Sanchiriro and Wyatt 2002; Hasler et al. 2005). The rainfall patterns often coincide with the effects of seasonality which in turn have an effect on the productivity of grassland pastures (Ospina et al. 2012). This could explain the consistent negative slope in forage quantity from the wet season to the dry season observed in this study.

\section{Pattern of land use/land cover change}

Over the last 27 years, it is apparent that land use and land cover within the different land covers of Karamoja have been changing. The changes have been nonuniform in the three time steps (1986 to 2000, 2000 to 2013 and 1986 to 2013) observed in the sub-region. Notable in the process of change is the considerable disappearance of woodlands, the rapid rise in croplands from 2000 to 2013 and the increase in woody vegetation associated with bushlands in the sub-region. Although the woodlands appear to be recovering in 2013, they are nonetheless lower than the 1986 period and perhaps even the earlier periods. Majaliwa et al. (2009) indicated that over the last 30 years, deforestation has been rapid in the region. Similarly, Miljkovic (2008), Quam (1997),
Magunda (2010) and Kagan et al. (2010) have also noted the deforestation levels in the sub-region.

The general trend in the loss of woodlands is attributable to three factors, the first of which is the increased cutting of hardwood trees for charcoal and firewood. During the field process, piles of charcoal and split firewood amounting to many tonnes could be observed along the roads and villages in mainly woodland areas of Abim, Napak (particularly Iriir), Moruita in Amudat district and Tokora area and Namalu in Nakapiripirit district. This pattern is a result of expansion of the charcoal belt to eastern and northern regions of Uganda as well as the increased demand in the urban areas surrounding the subregion to the west. However, to the Karamojong people, this is the only means available to circumvent the impacts of poverty, hunger and climatic variability. These practices have hitherto been identified as a host of maladaptation strategies employed in the sub-region following the loss of livestock (Quam 1997; Levine 2010). The second reason for the loss of woodlands is a breakdown in traditional institutions, in particular the control previously exerted by the elders over the youth with respect to natural resources management. This has allowed tree cutting to flourish unabated. Thirdly, expanding croplands are exerting pressure on woodland land cover. Locations where woodlands exist and are accessible to the communities are preferred for establishment of farmlands because they are believed to be fertile. During the interviews and focus group discussions, the soils in such areas were described as 'cool' and thus good for sorghum and maize production. 
Through the land use/cover change matrix, this study has unearthed a rapid increase in the agriculturalisation of once pastoral Karamoja. The increase in crop cultivation in tropical semi-arid and pastoral areas in Africa has been reported by studies elsewhere. For example, Ekaya (2005) reported a general increase of crop cultivation and sedentarisation over East Africa's drylands. Meanwhile Zziwa et al. (2012) observed an increase in croplands in Nakasongola, Uganda, while Tsegay et al. (2010) observed a similar trend in the Afar region of Ethiopia. Sulieman and Ahmed (2013) further observed that in eastern Sudan, state policies that favour crop farming over pastoralism were in part changing pastoral natural resources. In Karamoja, the increase in subsistence croplands can be explained by three factors. Firstly, the Government of Uganda has strengthened direct support for crop cultivation through provision of seeds and tractors. Tractors are provided to the communities to clear land for planting at zero or subsidized fees. This is viewed as a mechanism to stamp out persistent food insecurity in the region. Secondly, a similar effort is being exerted by development organizations, both local and international, through supporting agriculturalisation of the once pastoral society through provision of planting materials, gardens tools and seeds tied to 'food for work' systems. Thirdly, the persistent livestock raids that existed in the region prior to the 2000 to 2007 peaceful and forceful disarmament led to a high number of pastoralist dropouts. This group of people has been quick to adopt crop cultivation to ameliorate their deplorable livelihood situation. Having lost livestock to raids and being incapable of reconstituting herds through normal pastoral channels and/or through subversive means (raids), the option provided by the government and other development partners has become handy when faced with destitution. This crop cultivation option has largely gained ground because it is championed by those with a chlorophyll syndrome, that is those who believe in crops as the sole precept of food security.

As already pointed out in the 'Results' section, bushland encroachment is rapidly gaining hold and is threatening the existence of grasslands that once characterized the plains of Karamoja. The presence of some alien species such as Prosopis spp. (not yet wide spread but pronounced in Amudat district and a few pockets in Moroto and Kotido districts) will further encourage bushland encroachment in the sub-region in a few years to come. Prosopis spp. is already causing serious challenges in semi-arid areas of Kenya (Maundu et al. 2009). Prosopis spp. was introduced into semi-arid Turkana and Baringo areas of Kenya as part of rangeland rehabilitation in the 1980s and 1990s; it is however expanding into Karamoja as a result of Turkana transhumant herders. The Karamojong attribute its spread to the presence of the Turkana and Pokot camels. Elsewhere in Uganda, bushland encroachment has been observed to be high in the semi-arid areas. For example, it has been recorded in Nakasongola (Zziwa et al. 2012) and around the Kagera basin of Uganda (Tolo et al. 2012). Similarly, bushland encroachment has been noted in the semi-arid Afar region of Ethiopia (Tsegay et al. 2010) and in Laikipia (Causey and Lane 2005) and Mbeere districts (Kamau 2004) in Kenya.

Bushland encroachment in semi-arid regions has generally been attributed to a reduction in the use of fire as the traditional management strategy (e.g. Gemedo 2004) and the absence of grazing (Oba et al. 2000). Karamoja sub-region has not been an exception to these drivers, except that fire use in Karamoja is still evident. In Karamoja, however, other reasons exist for the development and increasing dominance of bushland vegetation.

Firstly, parts of northwestern Karamoja (e.g. Lotukei, Morulem, Garegere and parts of Alerek in Abim district; Karenga, Lodapal Kawanga and Lomaler in Kaabong district; and Apalopama, Lobul and Lomaria in Kotido district) were once affected by the LRA rebels during the late 1990s to mid-2000s. This prohibited the normal grazing calendar of the pastoralists in these locations which are traditionally dry season grazing grounds. This allowed bush encroachment to occur in these locations due to the absence of grazing. However, the absence of grazing in these locations also created pressure in the central plains that became heavily grazed, leading to the transformation of the vegetation into thicket and shrubland.

Secondly, the period from the mid-1980s to the mid2000s was marked by Karamoja at war with itself and without herself. This was mainly a result of the increased proliferation of small fire arms in the area which increased livestock raids. It thus became dangerous to venture outside defensive positions with one's animals because of the high risk of losing livestock to rustlers. During this time, normal grazing calendars became distorted and herders grazed livestock within the settlement vicinities and peripheries where immediate reinforcements could be mobilized in the event of attack. At the same time, the neighbouring communities such as the Turkana who often relied on the dry season pastures in eastern parts of Karamoja could not access such grazing grounds as they were a sworn enemy (Quam 1997). This allowed bushes to become dominant in the once expansive eastern grasslands, due to limited grazing.

Thirdly, out of the raids came the military restricted movement and protected kraal system. In this system, the military regulated where and how far the herders could take their animals for grazing. This was partly because the herders relied on the military for security in defense of their livestock. Thus, the movements could 
barely exceed $5 \mathrm{~km}$ from the manyattas (homesteads) and/or protected kraals, since going beyond this distance increased the vulnerability of both the herders and the military to attack from raiders. This, therefore, left large parts of the region inaccessible for grazing while the used areas were slowly encroached by bushlands, and heavily grazed areas were transformed into thickets and shrublands.

Finally, areas that had been croplands were rapidly encroached by bushlands because communities abandon such croplands once productivity declines. What is evident however is that bushland encroachment is affecting most of the dry season pastures in southeastern areas (e.g. parts of Karita, Lokales, Loporokocho and around Morunyang in Amudat district), in central to eastern areas (e.g. parts of Katekile, Lokwakipi, Lokisile, Mogos, Losagam, Kothoniok and Kobebe in Moroto district), in northeastern areas (e.g. Risai, Kamion, Oropoi, Kalapata and Pirre in Kaabong district) and in the parts of the southern rangelands in Nakapiripirit district among others.

Relationship between NDVI and herbaceous forage quantity The significant relationship observed between NDVI and conventionally clipped above-ground biomass is a good indication that remote sensing data can be applied in estimating forage quantity in the sub-region. The estimation equations obtained for both wet weight and dry matter biomass can thus be applied in a remote sensing environment. In a pilot study conducted in Kenya as part of a global assessment of land degradation and improvement, Bai and Dent (2006) also applied remote sensing successfully to quantify green biomass and net primary production. According to Bozkurt et al. (2011), remote sensing techniques provide greater flexibility and accuracy for grassland assessment, and the integration performed in this study has provided evidence in this direction. Further, Dwyer (2011) conducted a spatial estimation of herbaceous biomass using remote sensing in southern African savannas with great detail and success. Such assessments have been limited and/or virtually non-existent for Karamoja. This has been due to the lack of baseline information regarding forage quantity in different land covers. Also, for a considerable period of time (over three decades), the sub-region was plunged into civil strife exacerbated by the high proliferation of small arms. This made ground-based assessments involving forage clipping impossible in the sub-region. The situation has improved marginally, although the Turkana and Pokot of Kenya remain a security challenge because they are still armed and occasionally conduct armed livestock raids in the sub-region. Despite these challenges, this study has addressed the lack of groundbased assessments of forage quantity in the sub-region.

\section{Conclusion}

This study was commissioned with the main objectives of quantifying forage in the different grazing land use/ cover types in Karamoja and providing a long-term portrait of how these grazing land use/cover types have changed. This study has successfully bridged the information gap on forage quantity at seasonal and regional levels, thus fulfilling one of the recommendations made in the 10th EU/KALIP project document seeking for a full forage assessment on seasonal and location basis in the sub-region. We have not only provided a wet and dry season perspective, but have also provided a transitionary season view point which is critical in providing warning signals on the likely challenges that the pastoralists may face during the dry season.

It is hoped that this information should be able to trigger early preparation and early response to the plight of pastoralists and agro-pastoralists. This study has also highlighted the existence of spatial heterogeneity in different grazing land covers as well as districts in the region. Thus, mobile grazing practices as used in the region are likely to continue and may offer the best option for coping and adapting to the heterogeneity in the grazing landscapes as observed in this study. Furthermore, this study has shown that the grasslands, which represent the most important grazing land cover in the sub-region, are under threat from bushland encroachment. In particular, the proliferation of alien species such as Prosopis spp. will pose an even greater risk in a few years. This requires immediate management attention to reduce the evident bushland invasion.

Uniquely, this study has shown that while other grazing land covers decline in forage quantity during the dry season, the thickets and shrublands have their peak production during the transitionary season. The growth in cropping in the last 13 years is unprecedented. It is therefore imperative that while supporting intensification and increases in crop cultivation, efforts are also geared towards integrated livestock-crop production systems in the sub-region. Therefore, the sustainability of livestock grazing in the sub-region will depend on the health of the grasslands for continued mobile grazing practices in order to overcome the low forage quantity per hectare. This study has also shown that it is possible to estimate above-ground biomass using remote sensing technologies. The estimation equations developed in this study offer baseline information that could be utilised by decision-makers to rapidly obtain forage information status. The varied response rates of land covers at different locations demonstrate the heterogeneity within the land covers and locations in the sub-region. We recommend that long-term monitoring studies be conducted in the sub-region within three main treatments: no grazing, controlled grazing and open-access grazing. 


\section{Additional files}

Additional file 1: Herbaceous and woody plant species in Karamoja. Tables showing a list of herbaceous and woody plant species observed in grassland land cover (Table S2c) and list of herbaceous and woody plant species in woodland land cover (Table S2d).

Additional file 2: Correlation between above-ground wet weight biomass and NDVI. A table showing the relationship of NDVI and herbaceous forage quantity $\left(\mathrm{g} / \mathrm{m}^{2}\right)$ in Karamoja sub-region (Table S8).

\section{Competing interests}

The authors declare that they have no competing interests.

\section{Authors' contributions}

AE conducted field data collection and structured the manuscript, OW, LM and JM Provided technical guidance on methodology and article structure. GJMM and JK provided technical guidance in GIS and remote sensing including assistance in image processing.

\section{Author's information}

AE is a PhD student at University of Nairobi and an Assistant Lecturer at Makerere University, Uganda. OW (PhD), LM (PhD) and JM (PhD) are Lecturers at University of Nairobi. JK is an MSc. student at Makerere University, Uganda, and GJMM is an Associate Professor at Makerere University, Uganda.

\section{Acknowledgements}

This study was funded in part by a grant to Makerere University by the Carnegie Corporation of New York and Makerere University. Additional funding was provided by Regional Universities Forum for Capacity Building in Agriculture (RUFORUM). We are grateful to the Uganda People's Defense Forces (UPDF) for the provision of security at various locations in the region.

\section{Author details}

'Department of Land Resource Management and Agricultural Technology, University of Nairobi, P.O. Box 29053-00625, Nairobi, Kenya. ${ }^{2}$ German Institute for Tropical and Subtropical Agriculture (DITSL), University of Kassel, Steinstraße 19, Witzenhausen 37213, Germany. ${ }^{3}$ Department of Agricultural Engineering, Makerere University, P.O. Box 7062, Kampala, Uganda. ${ }^{4}$ Department of Geography, Geo-informatics and Climatic Sciences, Makerere University, P.O. Box 7062, Kampala, Uganda. ${ }^{5}$ Department of Agricultural Economics, University of Nairobi, P.O. Box 29053-00625, Nairobi, Kenya.

Received: 28 February 2014 Revised: 1 March 2014

Accepted: 30 April 2014

Published: 30 May 2014

\section{References}

Abusuwar, AO, and EO Ahmed. 2010. Seasonal variability in nutritive value of ruminant diets under open grazing system in the semi-arid rangeland of Sudan (South Darfur State). Agriculture and Biology Journal of North America 1(3):243-249.

Ahmed, AGM. 2009. Transforming pastoralism: A case study of the Rufa'a Al Hoi ethnic group in the Blue Nile State, Sudan. Nomadic Peoples 13(1):113-133.

Allen, VG, C Batello, EJ Berretta, J Hodgson, M Kothmann, X Li, J Mclvor, J Milne, C Morris, A Peeters, and M Sanderson. 2011. An international terminology for grazing lands and grazing animals. Grass and Forage Science 66:2-28.

Anderson, M, and WI Robinson. 2009. The 10th EDF Karamoja Livelihoods Programme (KALIP). Technical reference guide submitted to EU, Government of Uganda and FAO, Kampala.. Available from: www.opm.nulep.org/about.../ 436 f6ec429c540744f00d64b5ce83770ca. Accessed on $5^{\text {th }}$ January, 2014.

Angerer, JP. 2008. Technologies, tools and methodologies for forage evaluation in grasslands and rangelands. Texas: A \& M University.

Ashley, S, and W Nanyeenya. 2002. More than income: Pro-poor livestock development policy in Uganda. Livelihoods and Diversity Directions Explored by Research (LADDER) Working Paper No. 8. UK: UK Department for International Development (DFID).

Augustine, DJ. 2010. Spatial versus temporal variation in precipitation in a semi-arid ecosystem. Landscape Ecology 25: 913-925. doi: 10.1007/s10980010-9469-y.
Avery, S. 2014. Water development and irrigation in Karamoja, Uganda. A review report submitted to Dan Church Aid.. Available from: www.opm.nulep.org/buds.

Awa, DN, A Njoya, YM Logtene, JA Ndomadji, J Onana, A Asongwed-Awa, CAN Tama, M Djoumessi, B Loko, AB Bechir, A Delafosse, and A Maho. 2002. Livestock production systems in the semi-arid savannah of the Central African sub-region. Actes du Colloque, 27-31 mai 2002. Garoua: Cameroun. Available from: http://hal.archives-ouvertes.fr/hal-00137977/. Accessed on $7^{\text {th }}$ December, 2013.

Bai, ZG, and DL Dent. 2006. Global assessment of land degradation and improvement: A pilot study in Kenya. World Soil Information. Report 2006/1; Available from: http://www.isric.org/isric/webdocs/docs/ ISRIC Report 2006 01.pdf. Accessed on $2^{\text {nd }}$ August, 2013.

Barrow, E. 1988. Trees and pastoralists: The case of Pokot and Turkana. Social Forestry Network Network Paper 6b:1-27.

Bassett, TJ, and D Crumney. 2003. Contested images, contested realities: Environment and society in African savannas. In African savannas: Global narratives and local knowledge of environmental change, ed. TJ Bassett and D Crumney, 1-30. Oxford: James Currey Ltd.

Behnke, R, and M Nakirya. 2012. The contribution of livestock to the Ugandan economy. IGAD Livestock Policy Initiative Working Paper No. 02-12. Available from: http://cgspace.cgiar.org/bitstream/handle/10568/24970/ IGAD_LPI_WP_02-12.pdf. Accessed on $27^{\text {th }}$ April, 2014.

Best, RJ, and P Arcese. 2009. Exotic herbivores directly facilitate the exotic grasses they graze: Mechanisms for an unexpected positive feedback between invaders. Oecologia 159(1):139-150.

Bozkurt, Y, N Uzun, and C Dogan. 2011. Grassland evaluation based on GIS model and remote sensing data for beef cattle grazing. Grassland Science in Europe 16:490-492.

Campbell, DJ, DP Lusch, T Smucker, and EE Wangui. 2003. Root causes of land use change in the Loitokitok Area, Kajiado District, Kenya.. LUCID Working Paper Series No. 19

Causey, M, and P Lane. 2005. GIS and landscape archaeology: Delineating the possible long-term environmental effects of pastoralism on the Laikipia Plateau, Kenya. Nyame Akuma, No. 64:24-32. Available from: www.safa.rice. edu/Nyame_Akuma/NA.../Nyame_Akuma_Issue_064-Causey. Accessed on $3^{\text {rd }}$ February, 2014.

Crawley, MJ. 1983. Herbivory: The dynamics of animal-plant interactions (vol. 10). Berkley, California: University of California Press.

Dwyer, PC. 2011. Spatial estimation of herbaceous biomass using remote sensing in Southern African savannas, MSc. Thesis. Johannesburg: University of Witwatersrand

Dzowela, BH, L Hove, BV Maasdorp, and PL Mafongoya. 1997. Recent work on the establishment, production and utilization of multipurpose trees as a feed resource in Zimbabwe. Animal Feed Science and Technology 69(97):1-15.

Ekaya, W. 2005. The shift from mobile pastoralism to sedentary crop-livestock farming in the drylands of eastern Africa: Some issues and challenges for research. African Crop Science Conference Proceedings 7:1513-1519.

FAO. 2005. Uganda: Livestock sector brief. Rome: FAO.

Feng, Y, Q Lu, T Tokola, H Liu, and X Wang. 2009. Assessment of grassland degradation in Guinan county, Qinghai Province, China, in the past 30 years. Land Degradation Development 20:55-68.

Fensholt, R, I Sandholt, and MS Rasmussen. 2004. Evaluation of MODIS LAI, fAPAR and the relation between FAPAR and NDVI in a semi-arid environment using in situ measurements. Remote Sensing of Environment 91:490-507. 10.1016/ j.rse.2004.04.009.

Gambiza, J, E Chidumayo, H Prins, H Fritz, and P Nyathi. 2010. Livestock and wildlife. In The dry forests and woodlands of Africa, ed. EN Chidumayo and DJ Gumbo. London: Earthscan Ltd.

Gemedo, D. 2004. Vegetation ecology, rangeland condition and forage resources evaluation in the Borana lowlands, southern Oromia, Ethiopia. PhD, Thesis, Georg-August Universität Göttingen, Göttingen, Germany. Göttingen: Cuvillier.

Gintzburger, G, and S Saïdi. 2009. From inventory to monitoring in semi-arid and arid rangelands. In Range and animal sciences and resources management. Encyclopaedia of life support systems, ed. VR Squires. Oxford: EOLSS, UNESCO. Available at: www.eolss.net.

Grade, JT, JRS Tabuti, and P van Damme. 2009. Ethnoveterinary knowledge in pastoral Karamoja, Uganda. Journal of Ethnopharmacology 122:273-293. doi:10.1016/j.jep.2009.01.005. 
Hasler, N, R Avissar, and GE Liston. 2005. Issues in simulating the annual precipitation of a semi-arid region in Central Spain. American Metrological Society 6:409-422.

Iwaasa, AD, MP Schellenberg, and B McConkey. 2012. Re-establishment of native mixed grassland species into annual cropping land. Prairie Soils and Crops Journal 5:85-95.

Jeltsch, F, SJ Milton, WRJ Dean, N van Rooyen, and KA Moloney. 1998. Modelling the impact of small-scale heterogeneities on tree-grass coexistence in semi-arid savannas. Journal of Ecology 86:780-793.

Kagan, S, L Pedersen, S Ollech, and D Knaute. 2010. The Karamoja syndrome: transdisciplinary systems research informing policy and advocacy. www.cultura21.net/karamoja/docs/Karamoja_syndrome. Accessed 21 Jan 2014

Kamau, P. 2004. Forage diversity and impact of grazing management on rangeland ecosystems in Mbeere District, Kenya. LUCID Working Paper Series No. 36. International Livestock Research Institute (ILRI). Available from: www. lucideastafrica.org/publications/Kamau_LUCID_WP36.pdf. Accessed on 14 ${ }^{\text {th }}$ March, 2013.

Kawamura, K, and T Akiyama. 2010. Simultaneous monitoring of livestock distribution and desertification. Global Environmental Research 14/2010: 29-36.

Kirwa, EC, MM Nyangito, DM Nyariki, and RK Kimitei. 2012. Effect of land use changes on adaptive strategies for smallholder agro-pastoralists in Kenya. Livestock Research for Rural Development 24(8):2012.

Lambin, EF, HJ Geist, and E Lepers. 2003. Dynamics of land use and land cover change in tropical regions. Annual Review of Environment and Resources 28: 205-241.

Le Houerou, HN. 1980. The rangelands of the Sahel. Journal of Range Management 33(1): 41-45.

Lesorogol, CK. 2005. Privatizing pastoral lands: Economic and normative outcomes in Kenya. World Development 33(11): 1959-1978.

Levine, S. 2010. What to do about Karamoja: Why pastoralism is not the problem but the solution. A food security analysis of Karamoja. Uganda: FAO/ECHO Available from: www.celep.info/wp-content/uploads/.../what-to-do-aboutKaramoja.pdf. Accessed on $8^{\text {th }}$ December, 2013.

Lusigi, WJ, ER Nkurunziza, and S Masheti. 1984. Forage preferences in of livestock in the arid lands of Northern Kenya. Journal of Range Management 37(6): 542-548.

Madu, A. 2012. Spatial vulnerability of rural households to climate change in Nigeria: Implications for internal security. The Robert S. Strauss Center Working Paper No. 2.

Magunda, MK. 2010. Study on disaster risk management and environment for the Karamoja sub-region. Kampala, Uganda: European Commission and Food and Agriculture Organisation of the United Nations (FAO). Available from: www.fao.org/.../user.../Karamoja\%20Disaster\%20Risk\%20Reduction.pdf. Accessed on 5th January, 2014).

Majaliwa, MGJ, E Nkonya, F Place, J Pender, and P Lubega. 2009. Case studies of sustainable land management approaches to mitigate and reduce vulnerability to climate change in sub Saharan Africa: The case study of Uganda. Uganda: International Food Policy Research Institute (IFPRI) and Makerere University Institute of Environment and Natural Resources (MUIENR). 1-55

Maundu, P, S Kibet, Y Morimoto, M Imbumi, and R Adeka. 2009. Impact of Prosopis juliflora on Kenya's semi-arid and arid ecosystems and local livelihoods. Biodiversity 10(2-3): 33-50.

Miehe, S, J Kluge, H von Wehrden, and V Retzer. 2010. Long-term degradation of the Sahelian rangeland detected by 27 years of field study in Senegal. Journal of Applied Ecology 47:692-700. doi:10.1111/j.1365-2664.2010. 01815.x.

Miljkovic, A. 2008. Environment, security, and conflict: Exploring the linkage with a close up of Uganda's region of Karamoja. Lille: Sciences Po.

Ministry of Agriculture Animal Industry and Fisheries (MAAIF) and Uganda Bureau of Statistics (UBOS). 2010. National Livestock Census Report 2008. Kampala: MAIF and UBOS.

Nakalembe, CL. 2013. Estimating agricultural land use change in Karamoja, NE. Uganda using very high resolution satellite data. In AGU Fall Meeting Abstracts vol. 1, 0369. Available from: http://adsabs.harvard.edu/abs/ 2013AGUFM.B41A0369N. Accessed on 13 ${ }^{\text {th }}$ December, 2013.

Nalule, AS. 2010. Social management of rangelands and settlements in Karamoja. Uganda, Kampala: FAO and EU, Uganda. Available from: www.fao.org/../1_Social \%20Management\%20of\%20Rangelands\%20in. Accessed on 5 $5^{\text {th }}$ November, 2013.
Nelson, F. 2012. Natural conservationists? Evaluating the impact of pastoralist land use practices on Tanzania's wildlife economy. Pastoralism: Research, Policy and Practice 2:15.

Notenbaert, AM, J Davies, J De Leeuw, M Said, M Herrero, P Manzano, M Waithaka, A Aboudi, and S Omondi. 2012. Policies in support of pastoralism and biodiversity in the heterogeneous drylands of East Africa. Pastoralism: Research, Policy and Practice 2:14.

Nyariki, DM, AW Mwang'ombe, and DM Thompson. 2009. Land-use change and livestock production challenges in an integrated system: The Masai-Mara ecosystem, Kenya. Human Ecology 26(3):163-173.

Oba, G. 2012. Harnessing pastoralists' indigenous knowledge for rangeland management: Three African case studies. Pastoralism: Research, Policy and Practice 2:1.

Oba, G, E Post, PO Syvertsen, and NC Stenseth. 2000. Bush cover and range condition assessments in relation to landscape and grazing in Ethiopia. Landscape Ecology 15:535-546.

Ooro-Olang, MO. 1984. Vegetation cover assessment in Turkana District, Kenya, 183-206.. Available from: www.content.alterra.wur.nl/.../Proceeding\%20of\% 20the\%20workshop\%20leeg. Accessed on $3^{\text {rd }}$ February, 2014.

Ospina, S, GM Rusch, D Pezo, F Casanoves, and FL Sinclair. 2012. More stable productivity of semi-natural grasslands than sown pastures in a seasonally dry climate. PloS One 7(5): e35555. doi: 10.1371/journal.pone.0035555.

Peng, J, J Wu, H Yin, Q Chang, and T Mu. 2008. Rural land use change during 1986-2002 in Lijiang, China, based on remote sensing and GIS data. Sensors 8: 8201-8223. doi:10.3390/s8128201.

Quam, D. 1997. Creating peace in an armed society: Karamoja, Uganda, 1996. African Quarterly Studies 1(1):33-46.

Quam, MD. 1999. A bibliography of Karamoja, Uganda: Books and articles published in English. Electronic Journal of Africana Bibliography 5(1). Available from: www.ir.uiowa.edu/ejab/vol5/iss1/. Accessed on $3^{\text {rd }}$ February, 2014.

Reid, RS, S Serneels, M Nyabenge, and J Hanson. 2005. The changing face of pastoral systems in grass-dominated ecosystems of eastern Africa. In Grasslands of the world, no. 34, ed. JM Suttie, SG Reynolds, C Batello, JM Suttie, SG Reynolds, and C Batello. Food and Agriculture Organisation of the United Nations, FAO.

Ruelland, D, F Levavasseur, and A Tribotte. 2010. Patterns and dynamics of land-cover changes since the 1960s over three experimental areas in Mali. International Journal of Applied Earth Observation and Geoinformation 12:11-17.

Sanchiriro, JN, and TJ Wyatt. 2002. Spatial heterogeneity, mobility and access: The case of range management in the Sahel, Quality of the Environment Division, Resources of the Future, Washington DC.. Available from: www. researchgate.net. Accessed on 31 $1^{\text {st }}$ January, 2014.

Scholte, P, and J Brouwer. 2008. Relevance of key resource areas for large-scale movements in livestock. In Resource ecology: Spatial and temporal dynamics of foraging, ed. HHT Prins and F van Langevelde, 211-232. Dordrecht: Springer.

Scott-Villiers, P. 2013. Ekoi and Etem in Karamoja - A study of decision-making in a post-conflict society. A Report submitted to Karamoja Action Research Team.. Available from: www.restlessdevelopment.org/file/ekoi-and-etem-inkaramoja-dec-13-pdf. Accessed on $25^{\text {th }}$ February, 2014.

Sulieman, HM, and AHM Ahmed. 2013. Monitoring changes in pastoral resources in eastern Sudan: a synthesis of remote sensing and local knowledge. Pastoralism: Research, Policy and Practice 3:22.

Tabuti, JRS, and KA Lye. 2009. Fodder plants for cattle in Kaliro District, Uganda. African Study Monographs 30(3):161-170.

Tenuche, MS, and OO Ifatimehin. 2009. Resource conflict among farmers and Fulani herdsmen: Implications for resource sustainability. African Journal of Political Science and International Relations 3(9):360-364.

Thomas, AS. 1943. The vegetation of the Karamoja district, Uganda: An illustration of biological factors in tropical ecology. Journal of Ecology 31(2):149-177.

Tolo, CU, EA Majule, and J Perfect. 2012. Changing trends of natural resources degradation in Kagera basin: Case study of Kagera sub-basin, Uganda. Natural Resources 3:95-106.

Tsegay, D, SR Moe, P Vedeld, and E Aynekulu. 2010. Land use/cover dynamics in northern Afar rangelands, Ethiopia. Agriculture, Ecosystems and Environment 139: 174-180. doi:10.1016/j.agee.2010.07.017.

Undersander, D, DR Mertens, and N Thiex. 1993. Forage analyses procedures. Omaha: National Forage Testing Association.

Wamani, H, and A Bagonza. 2013. Nutrition and food security assessment in Karamoja. A Report submitted to UNICEF-Uganda. Available from: www.klikuganda.com/ downloads/Karamoja_Dec_2012_report.pdf. Accessed on 25 th February, 2014. 
Weber, KT, and S Horst. 2011. Desertification and livestock grazing: The roles of sedentarisation, mobility and rest. Pastoralism: Research, Policy and Practice 1:19.

Xie, Y, Z Sha, and M Yu. 2008. Remote sensing imagery in vegetation mapping: A review. Journal of Plant Ecology 1(1):9-23.

Zziwa, E, G Kironchi, C Gachene, S Mugerwa, and D Mpairwe. 2012. The dynamics of land use and land cover change in Nakasongola district. Journal of Biodiversity and Environmental Sciences 2(5):61-73.

10.1186/2041-7136-4-6

Cite this article as: Egeru et al:: Spatio-temporal dynamics of forage and land cover changes in Karamoja sub-region, Uganda. Pastoralism: Research, Policy and Practice 2014, 4:6

\section{Submit your manuscript to a SpringerOpen ${ }^{\circ}$} journal and benefit from:

- Convenient online submission

- Rigorous peer review

- Immediate publication on acceptance

- Open access: articles freely available online

- High visibility within the field

- Retaining the copyright to your article

Submit your next manuscript at $\gg$ springeropen.com 